\title{
Compliance with goodwill related mandatory disclosure requirements and the cost of equity capital
}

\author{
Francesco Mazzi \\ Paul André* \\ Dionysia Dionysiou \\ Ioannis Tsalavoutas
}

\section{Accepted for publication in Accounting and Business Research}

\section{Acknowledgements}

We gratefully acknowledge helpful comments received from Juan Manuel Garcia Lara (the Joint Editor), Ann Tarca (the Associate Editor), two anonymous reviewers, Dr Amir Amel-Zadeh and Dr Alan Teixiera (the two discussants at the inaugural IASB Research Forum, Oxford, October 2014), Saverio Bozzolan, Joachim Gassen, Alan Goodacre, Stergios Leventis, Chrystodoulos Louca, Musa Mangena, the seminar participants at the Division of Accounting and Finance at the University of Stirling (November, 2012), the participants of the 49th BAFA Annual Conference (Newcastle, April 2013), the participants of the 36th Annual Congress of the EAA (Paris, May, 2013), the participants of the Scottish BAFA (Glasgow, September, 2013), the participants of the 9th EUFIN Workshop (Valencia, September 2013), and the participants of the 12 ${ }^{\text {th }}$ IAEER World Congress (Florence, November, 2014). Francesco Mazzi thanks the Ordine Dottori Commercialisti ed Esperti Contabili (ODCEC) of Florence and Fondazione Dottori Commercialisti ed Esperti Contabili (FDCEC) of Florence for financial support. Paul André, Dionysia Dionysiou and Ioannis Tsalavoutas thank the Association of Chartered Certified Accountants (ACCA) for financial support. Paul André also thanks the ESSEC KPMG Financial Reporting Centre for additional financial support.

*Correspondence author.

Paul André is at HEC Lausanne (UNIL, CH-1015, Lausanne, Switzerland. E-mail address: paul.andre@unil.ch). Francesco Mazzi is at The University of Florence (Economics and Management School, Accounting and Finance Division, Via delle Pangette 9, Building D6, 50127, Florence, Italy, E-mail: francesco.mazzi@unifi.it).

Dionysia Dionysiou is at The University of Stirling (Stirling Management School, Accounting and Finance Division, FK9 4LA, Scotland, UK. E-mail: Dionysia.Dionysiou@stir.ac.uk).

Ioannis Tsalavoutas is at the University of Glasgow (Adam Smith Business School, West Quadrangle, Main Building, Room G683, University Avenue, Glasgow, G12 8QQ, Scotland, UK. E-mail: Ioannis.Tsalavoutas@glasgow.ac.uk). 


\title{
Compliance with goodwill related mandatory disclosure requirements and the cost of equity capital
}

\begin{abstract}
Theory suggests that increased levels of corporate disclosure lead to a decrease in cost of equity via the reduction of estimation risk. We examine compliance levels with IFRS 3 and IAS 36 mandated goodwill related disclosure and their association with firms' implied cost of equity capital (ICC). Using a sample of European firms for the period 2008 to 2011, we find a median compliance level of about $83 \%$ and significant differences in compliance levels across firms and time. Non-compliance relates mostly to proprietary information and information that reveals managers' judgment and expectations. Overall, we find a statistically significant negative relationship between the ICC and compliance with mandated goodwill related disclosure. Further, we split the sample between firms meeting (or not) market expectations about the recognition of a goodwill impairment loss in a given year to study whether variation in compliance levels mainly plays a confirmatory or a mediatory role. We find the latter: higher compliance levels matter only for the sub-sample of firms that do not meet market expectations regarding goodwill impairment. Finally, our results hold only in countries where enforcement is strong.
\end{abstract}

Keywords: Accounting disclosure, compliance, cost of equity capital, goodwill, IAS36, IFRS3, impairments.

JEL Classifications: M40, M41, M48, G10. 


\section{Introduction}

We test the relationship between firms' compliance with goodwill related disclosure (as mandated by International Financial Reporting Standard (IFRS) 3 Business Combinations and International Accounting Standard (IAS) 36 Impairments of Assets) and their implied cost of equity capital (ICC). We expect it to be negative: a higher degree of compliance should reduce estimation risk or parameter uncertainty and, thus, the ICC. Second, we argue that a firm that recognises a goodwill impairment loss when not expected to do so (or vice versa) surprises investors, leading them to search for new information. Thus, higher compliance with goodwill related mandatory disclosure requirements should play a more informative role in these cases.

Goodwill recognised in a business combination is an asset representing future economic benefits arising from expected synergies not individually identified and separately recognised. Thus, goodwill conveys current- and forward-looking corporate information. Additionally, by definition, goodwill is an asset, the benefits of which, and contribution to a company's estimated future cash flows, are difficult to estimate - especially for someone without inside information. The anticipation and estimation of a potential impairment of goodwill is equally difficult. To minimise the estimation risk arising from goodwill recognition and measurement, IFRS requires firms to disclose specific information to inform users on how and why goodwill arises in business combinations. Further, IAS 36 contains disclosure requirements that 'are designed to improve the reliability of the impairment test' (IAS 36, Basis for conclusions, paragraph 198), which is primarily based on managerial assumptions and proprietary information. These disclosures include managerial explanations about recognition of an impairment, how future cash flows are forecasted, and what discount rates and terminal growth assumptions are used. Varying levels of compliance with these requirements impact investors' abilities to better estimate the amount, timing, and uncertainty of an entity's future net cash inflows across firms. This is critical given the ample evidence that analysts do use impairment information from the footnotes in their decision-making process (e.g., EY 2010, FRC 2014, 
KPMG 2014) and that compliance levels with regard to this topic in particular vary substantially across firms (ESMA 2013, Glaum et al. 2013).

We analyse a sample of non-financial constituents from Standard and Poor's Europe 350 (S\&P EU350) index over a period of four years (2008-2011). We use a disclosure checklist consisting of more than 50 items mandated by IFRS 3 and IAS 36, and manually check each of our sample firms for compliance. Subsequently, we compute two country-specific disclosure scores and one that treats our sample firms as a homogenous group. Then, we employ OLS and year fixed effects panel regression techniques, as suggested by Nikolaev and van Lent (2005), to identify whether the relationship of these disclosures with ICC is indeed negative, while controlling for other factors. We document that the median degree of compliance with goodwill related mandatory disclosure is around $83 \%$ but we also observe significant differences across firms. Further, we find a significant positive trend in compliance scores from 2008 to 2011, suggesting that these disclosures vary over time.

In addition, we examine the specific paragraphs for which we find high non-compliance. These paragraphs, inter alia, relate to assumptions and estimations used in the value in use calculations needed for making impairment decisions. Differential compliance levels with these disclosures across firms are particularly important as these have been shown to have information content (Al Jifri and Citron 2009) and relevance in assessing the implementation quality of the goodwill impairment tests (Hoogendoorn 2006, Carlin and Finch 2009, 2010, Bens et al. 2011, Li et al. 2011, Mazzi et al. 2016). Moreover, a 2014 report of the Accounting Standard Board of Japan (ASBJ), the Italian Standards Setter (OIC) and the European Financial Reporting Advisory Group (EFRAG) (ASBJ et al., 2014) indicates that preparers believe that these disclosure requirements force their companies to disclose potentially sensitive proprietary information. 
Overall, we find a negative and statistically significant association between compliance levels with goodwill related disclosure requirements and ICC. Our analyses across the subsamples of companies meeting (or not) market expectations about recognition of goodwill impairments reveal that compliance levels are associated with ICC only for firms not meeting market expectations. Increased disclosure assists investors in understanding why a firm impaired its goodwill (or not) only when this contradicts their expectations: greater compliance leads to a reduction of parameter uncertainty about future cash flow estimates. Further, we report evidence that these results hold only in countries with high enforcement.

We contribute to prior research in the following ways. First, we respond to calls for research on the economic consequences of disclosures mandated by accounting standards (Bushee and Leuz 2005, Leuz and Wysocki 2016), for which evidence is sparse. Prior empirical studies focus mainly on information disclosed on a voluntary basis (e.g., Botosan and Plumlee 2002, Hail 2002, Gietzmann and Ireland 2005, Francis et al. 2008, Dhaliwal et al. 2011, Blanco et al. 2015). Yet, compliance levels vary across firms and time, reflecting a likely trade-off between litigation costs resulting from non-disclosure (Skinner 1994) and proprietary costs resulting from disclosure (Verrecchia 2001). Second, our findings add to the strand of literature asserting that information matters depending on users' expectations. In fact, our results hold only across the sub-sample of companies not meeting the market's expectations about goodwill impairments and shed more light on when we might expect benefits from better disclosure, i.e., when it is most likely to help with the estimation of future earnings and cash flows.

Our findings should appeal to regulators who call for academic research to assist in the development of more evidence-informed accounting standard-setting (Teixeira 2014) and to financial statement preparers who must weigh the cost and benefits of their financial reporting choices. The significant differences in the compliance levels we report indicate that regulators need to address some deficiencies in the quality of financial reporting even among the largest 
EU firms. This complements the 'Summary of research evidence' within the Feedback Statement of the IASB's IFRS 3 Post Implementation Review (IASB 2015). Moreover, reflecting on standard setters' and regulators' recent concerns (e.g., EFRAG et al. 2012, FRC 2012, ESMA 2013, Hoogervorst 2013, IASB 2013) about the usefulness of disclosures required by accounting standards, we show those in IFRS 3 and IAS 36 can be important.

The remainder of the paper is organised as follows. Section 2 provides the theoretical framework and the testable hypotheses. Section 3 describes the sample selection process and the research design. Section 4 presents and discusses the empirical findings. Section 5 contains additional tests and Section 6 concludes.

\section{Goodwill related disclosure and the cost of capital}

There is an ongoing debate as to whether better information (disclosure) leads to lower cost of capital (Lambert et al. 2007, Hughes et al. 2007, Lambert et al. 2012, Bertomeu and Cheynel 2016). One possible channel through which disclosure would reduce cost of capital is via the reduction of estimation risk (Botosan 1997). The underlying argument about estimation risk is that securities for which less information is available are riskier because of greater uncertainty surrounding the exact parameters of their return distribution (Coles et al. 1995, Clarkson et al. 1996). Thus, higher firm disclosure may reduce estimation risk and cost of capital. This theory, however, critically depends on the non-diversifiable nature of information risk (Beyer et al. 2010). Prior studies examine estimation risk in relation to the cost of capital, considering corporate disclosure as a signal of future cash flows changes (e.g., Hughes et al. 2007, Lambert et al. 2007, 2012). Corporate disclosure may change a firm's value by affecting managerial decisions, thus altering the distribution of future cash flows (Leuz and Wysocki 2016). For example, the covariance between the cash flows of two firms decreases as disclosure in at least one of the two increases. Such a covariance decrease reduces the cost of capital, since this information effect is non-diversifiable (Lambert et al. 2007). 
Despite the existence of lengthy disclosure requirements in accounting standards, prior empirical studies mostly examine the effects of differential levels of voluntary disclosure (e.g., Botosan and Plumlee 2002, Hail 2002, Gietzmann and Ireland 2005, Francis et al. 2008, Dhaliwal et al. 2011, Blanco et al. 2015). Evidence regarding the economic consequences of compliance with mandatory disclosures remains largely unexplored (Bushee and Leuz, 2005, Leuz and Wysocki, 2016), as scholars make the false assumption that companies fully comply with regulated disclosures. Evidence in the accounting literature (e.g., Abdullah et al. 2015; Glaum et al. 2013) reveals that this is not true. The existence of a standardised framework with which users can easily identify whether a company provides all information required and/or which particular pieces of information are absent, however, allows for the exact information/item that companies are expected to disclose (and accounting standards mandate) to be easily identifiable in specific parts of an annual report. Thus, it would be inappropriate (if not misleading) to rely only on evidence referring to the impact of differential levels of voluntary disclosure on the cost of capital. Omitted disclosures via non-compliance with accounting standards may constitute a correlated omitted variable, leading to biased estimations. For this reason, Botosan (2006) calls for additional research that investigates the relationship between different types of disclosure and the cost of equity. Likewise, Gietzmann and Trombetta (2003, p. 187) state that 'communication via voluntary disclosure need not be a simple substitute for communication via accounting policy choice' (the latter is part of disclosure mandated by accounting standards). Easley and O'Hara (2004) add that the underprovision of public information is possible without required disclosure, suggesting the importance of voluntary disclosure on a firm's cost of capital being exacerbated if the degree of compliance with required disclosure is ignored.

Theory also suggests that accounting policy disclosure - effectively mandated by accounting standards - enables financial statement users to gather information about underlying 
accounting practices and, consequently, about a firm's private information (Dye 1985). Hope (2003) finds that disclosing accounting policies in an annual report is important to analysts, is more useful than other annual report disclosures, and is capable of reducing uncertainty about forecasted earnings. Harris and Morsfield (2012) document that virtually all investors and analysts who participate in their roundtable discussions and interviews, claim that they "extremely" or "very" often require data found only in the footnotes. More closely related to our study, findings from an EY (2010) survey indicate that most investors, analysts and lenders use impairment information disclosed in financial statements in their investment or lending decision-making processes. Similar evidence is reported in surveys conducted by FRC (2014) and KPMG (2014).

Goodwill often represents a significant amount on a company's balance sheet and has a distinct nature. It represents the excess of the purchase price over the acquirer's interest in the fair value of identifiable assets and liabilities acquired as at the day of the transaction. In other words, goodwill recognised is an asset that represents future economic benefits arising from synergies (that are not individually identified and separately recognised) between the identifiable and non-identifiable assets acquired. Thus, it conveys relevant current- and forward-looking information.

Investors are interested in understanding why a company proceeds with a specific acquisition (e.g., access to intellectual property, access to markets and/or synergies). Chauvin and Hirschey (1994) show that goodwill accounting data offer a useful perspective on the hardto-measure ongoing concern (reputational) value component of a firm's economic value. A number of papers show that the recognised value of goodwill itself is value relevant (e.g., McCarthy and Schneider 1995, Barth and Clinch 1996, Jennings et al. 1996). More relevant to our study, Al Jifri and Citron (2009) investigate both financial statement recognition and note disclosure, concluding that both aspects are correlated with share price. Paugam et al. (2015) 
show that the purchase price allocation is informative. Henning et al. (2000) also find that investors attach valuation weights to the identifiable components of purchased goodwill. Finally, Lee (2011), Lys et al. (2012) and Chalmers et al. (2012) find that goodwill is linked to future performance. Based on the above, we argue that recognised goodwill related disclosure conveys valuable information that reduces information risk.

Another strand of research is focused on the information content of goodwill write-offs (e.g., Bens et al. 2011, Li et al. 2011). Li et al. (2011, p. 747) show that investors and financial analysts revise their expectations downwards following an impairment loss announcement and conclude that 'the impairment loss thus appears to be a leading indicator of a decline in the future profitability'. Hirschey and Richardson (2002) indicate that such losses result in negative valuation effects. Disclosure of such losses, however, should be accompanied by important information regarding business risks, assumptions used and predictions made in the impairment testing. Otherwise, goodwill impairment testing process gives rise to concerns about its implementation quality (e.g., opportunistic selection of discount rates used in impairment testing: Hoogendoorn 2006, Carlin and Finch 2009, 2010). Indicative of the opportunistic use of goodwill impairment is the recent evidence by André et al. (2015) who show cross-sectional variation in conditional conservatism linked to goodwill impairment decisions.

The estimation of the goodwill recoverable amount relies on management expectations about the results of future actions driven by firm strategy. Disclosures that shed light on the assumptions and estimations considered during the impairment testing should enable financial statement users to gather information about firm private information (Dye 1985) and should reduce uncertainty about forecasted earnings (Hope 2003). Since real expectations and managerial private information are unobservable (Riedl 2004), such information cannot be fully verified by external stakeholders, unless managers disclose them. Thus, we further argue that 
mandated information related to goodwill impairment testing also conveys relevant information and reduces information risk.

Theory also suggests that compliance with disclosures mandated by accounting standards forces companies 'to disclose verifiable fundamentals based on past transactions and events, such as cash flows, profits, assets, and liabilities [which] essentially "grounds" expectations, making it harder for bubbles to occur' and facilitating market stability (Leuz and Wysocki 2016, p. 600). Mandatory disclosures also bind companies to disclose both good and bad news (Verrecchia 2001). This may provide incentives for non-compliance, opposing the expected or intended outcomes of accounting regulators: a manager aiming to maximise the firm's value will be reluctant to disclose potentially harmful information for the company's value (Dye 1986). Then again, to avoid 'litigation costs', a company may comply with mandated disclosures, even if they have to disclose proprietary information or bad news (Skinner 1994).

Even in countries where enforcement is very strong, like the US, non-compliance with mandatory disclosure requirements is evident (Robinson et al. 2011, Ayers et al. 2015). Thus, managerial incentives are strong and prevail over litigation risks when it comes to disclose proprietary information, albeit mandated by accounting standards. Hence, financial statement users receive variable levels of mandated information across firms, which can have an impact on the firm's information risk.

IFRS 3 focuses mainly on positive and negative goodwill that arises in business combinations finalised during the financial year. It thus mandates important information regarding purchase price allocation, amount of goodwill arising from the business combination and a description of factors that make up the goodwill (and/or negative goodwill) recognised, resulting in the provision of important signals to the market. IAS 36 mainly relates to the allocation of existing goodwill to Cash Generating Units (CGUs) and estimation of its recoverable amount. It requires information including cash flow projection periods, growth 
rates, discount rates and events / circumstances that lead to impairment loss recognition. We argue that information mandated by IAS 36 and IFRS 3 related to goodwill conveys relevant information to the financial markets and reduces information risk. Based on information risk theory that posits an association between the degree of compliance with relevant disclosures and the cost of equity capital, we set and test the following directional hypothesis:

H1: A higher degree of compliance with goodwill-related mandatory disclosure requirements is negatively associated with the cost of equity capital.

Investors are also interested in understanding whether a company achieves its original objectives with regard to an acquisition. Although an impairment does not affect an entity's current cash flows, being able to predict an impairment is an important input to investors' assessment of the amount, timing and uncertainty of (the prospect for) future net cash inflows. If the performance of certain CGUs or individual subsidiaries is deteriorating, users will lower their previous future cash flows and returns forecasts.

Given that market participants seem able to anticipate the recognition of an impairment loss (Bens et al. 2011, Ramanna and Watts 2012, Knauer and Wöhrmann 2016), we claim that the importance of compliance with goodwill related disclosure differs with whether a firm meets this market expectation or not. We predict that the market has a relatively lower estimation risk when a firm meets the market's expectation (i.e., it is expected to impair goodwill and does so or it is not expected to impair and does not do so) than when a firm does not meet expectations (i.e., does not impair when expected to do so or impairs when not expected to do so). We know that investors react more negatively to goodwill impairment announcements when an unverifiable explanation by management is provided (Knauer and Wöhrmann, 2016).

We argue that a firm that does not meet the market's expectation, surprises investors, leading them to seek more information. Not meeting the market's expectation implies 
potentially less a priori information available about these firms. Thus, higher levels of compliance with goodwill related mandatory disclosure have a more important role in shedding light on why a firm acts contrary to expectations. When market expectations are not met, increased disclosure (via higher compliance) assists in a better understanding of the firm's future returns distribution, reducing estimation risk and in turn, cost of equity capital (Coles et al. 1995, Clarkson et al. 1996). Instead, when companies meet market expectations, increased disclosure has less value as the market is able to anticipate the recognition or not of an impairment loss. We set and test the following directional hypothesis:

H2: The negative association between the degree of compliance with goodwill related mandatory disclosure requirements and the cost of equity capital is higher (lower) for firms that do not meet (meet) market expectations with regard to the recognition of a goodwill impairment loss.

\section{Research design}

\subsection{Sample and measurement of goodwill related mandatory disclosure levels}

We use a final sample of 831 firm-year observations, relating to 214 non-financial firms included in the S\&P EU350 index at least once during 2008 to 2011 (avoiding survivorship bias by not requiring firms to be in the index for all years tested). Table 1 summarises the sample selection process, the criteria on which firms are selected and the number of observations excluded. Table 1 also provides a country-industry classification. Briefly, most sample firms are listed in the UK and France and are part of the Industrials, Consumer Services and Consumer Goods ICB industry sectors.

\section{TABLE 1 - ABOUT HERE}

We focus on the disclosures related to goodwill within IFRS 3 and IAS $36 .{ }^{1}$ We develop a disclosure checklist to score compliance for each firm-year. Since $1^{\text {st }}$ July 2009 , revised

\footnotetext{
${ }^{1}$ IAS 38 Intangible Assets also requires some information which could be relevant to goodwill. This is already contained in IFRS 3 . To avoid double counting information required by more than one standard, our checklist is designed to include items only from the most relevant standard (Tsalavoutas et al. 2010).
} 
versions of IFRS 3 and IAS 36 have come into force, amending mandatory disclosure requirements. To account for the differences introduced and to identify the appropriate individual disclosure items, we draw up two different checklists: one for the 2008 and 2009 periods (hereafter, old checklist) and another for the 2010 and 2011 periods (hereafter, new checklist). ${ }^{2}$ We take into consideration the financial year-ends of our sample firms and we make sure that the appropriate checklist is used for each year under examination: if the first financial year for a company begins after $1^{\text {st }}$ July 2009 (finishes after 30 June 2010), the revised IFRS 3 and IAS 36 are applicable. Thus, the information captured derives from the new checklist and is under the 2010 financial year.

Within these checklists, first, we only consider goodwill related information that preparers are required to provide. ${ }^{3}$ Second, we exclude information that the standards encourage firms to disclose, but disclosure is not mandatory. ${ }^{4}$ Third, considering that the standards subdivide disclosure requirements across many sub-paragraphs, we use the information down to the last level of disaggregation. ${ }^{5}$

As it is common in this literature (e.g., Cooke 1992, Camfferman and Cooke 2002), we establish the content validity ${ }^{6}$ of the research instrument by adopting the following procedures. Both the old and new checklists were initially designed independently by each co-author and a first draft was the outcome of reaching consensus among the authors' lists. Then, the input of an independent, experienced, and professionally qualified practitioner was sought to further

\footnotetext{
${ }^{2}$ For example, paragraph 134-e of the revised IAS 36 requires three new pieces of information to be provided for fair value measurement if the discounted cash-flow method is used (134-e-iii, 134-e-iv and 134-e-v).

${ }^{3}$ The items we focus on are those listed in the sections 'Disclosures' in each standard, are written in bold fonts and the sentence 'an entity (or an acquirer) shall disclose...' precedes them.

${ }^{4} \mathrm{We}$ control for the potential effect of other disclosures on ICC while performing our multivariate analyses.

${ }^{5}$ As an example, Appendix A illustrates how the disaggregation issue is dealt with as regards to the disclosures required by IAS 36 paragraph 134 and sub-paragraph $\mathrm{d}$.

${ }^{6}$ Content validity refers to the adequacy of the instrument to measure the concept of interest (disclosure levels in this case). Content validity is achieved when a group of expert judges evaluates the items which are supposed to measure the concept and ensure that they, in fact, do so.
} 
discuss the list. The final old checklist contains 51 items (21 from IFRS 3 and 30 from IAS 36) and the new checklist contains 54 items (21 from IFRS 3 and 33 from IAS 36). ${ }^{7}$

The process of calculating mandatory disclosure levels for all sample firms is as follows. If a required item is disclosed, it is scored as 1 and if not, it is scored as 0 . In case an item is not applicable to a company, it is scored as 'not applicable' (NA) (Cooke 1992). Since only material items should be disclosed, applicability is an issue in these types of studies. Further, disclosure requirements relate to three aspects: carrying amount of existing goodwill, goodwill impairment losses and goodwill arising from a business combination in the current year. We consider these aspects/issues in the following way. First, every firm in the sample has goodwill which accounts for at least $5 \%$ of the book value of shareholders equity, a level that the European Securities and Market Authority (i.e., the regulators) considers material (ESMA 2011). Thus, we view all goodwill related disclosures as applicable for all our firms. Second, we apply the following criteria for ensuring that specific items related to material goodwill impairment losses and material business combinations, in particular, are applicable. First, given that recognition of a material goodwill impairment loss triggers more disclosures, we consider a material goodwill impairment loss to take place if it accounts for more than $5 \%$ of goodwill, as at the beginning of the year. Second, given that a material business combination triggers further disclosures, we consider a business combination to be material if the purchase price accounts for more than $5 \%$ of the company's total assets or sales, as at beginning of the year. This threshold also applies to business combinations that a firm reports to be individually immaterial but collectively material. To avoid penalising a company for not disclosing an item and for ensuring that an item is not applicable, we carefully read not only the notes to the financial statements but also the whole annual report before scoring this particular item. To ensure that we do not miss any

\footnotetext{
${ }^{7}$ Detailed checklists are available upon request.
} 
relevant information, we also scan the electronic version of each annual report, looking for the keywords: IAS 36, IFRS 3, business combination, impairment, goodwill, acquisition, negative goodwill, and bargain purchase.

A disclosure index for each company is then calculated as the ratio of the total items disclosed to the maximum possible score applicable for that company:

$$
C_{j}=\frac{T=\sum_{i=1}^{n} d_{i, j}}{M=\sum_{i=1}^{m} d_{i, j}}
$$

where $C_{j}$ is the total compliance score for each company and $0 \leq C_{j} \leq 1 . T$ is the total number of items disclosed $\left(d_{i}\right)$ by company $j$ and $M$ is the maximum number of applicable disclosure items for company $j$ (and with which compliance is expected) (see Hodgdon et al. 2008, Tsalavoutas 2011, Glaum et al. 2013). ${ }^{8}$

Prior literature on compliance with mandatory disclosures as well as our own validating tests (Appendix B) indicate that a variation in compliance levels is associated inter alia with a country's enforcement mechanisms, legal origin, financial structure and other country specific characteristics. Hence, to avoid our score picking up a country effect on ICC, following Francis et al. (2005), we derive two country-specific scores for each firm on an annual basis. The first metric (DiscScaled) is the difference between a firm's disclosure and the country-minimum (in our sample), scaled by the country-minimum score. This represents a relative percentage increase in mandatory disclosure related to goodwill over the country-minimum level in any given year. The second metric (DiscRaw) is the company's score over and above the countryminimum score the firm is incorporated in (again based on our sample firms). This represents the actual increase in compliance at the country level in any given year. These measures capture

\footnotetext{
${ }^{8}$ Tsalavoutas et al. (2010) and Tsalavoutas (2011) discuss the potential benefits of separating the items across different standards (in our case, separating across IFRS 3 and IAS 36), by first calculating compliance with each grouping and then weighting them equally. This method focuses on compliance with standards (or other groupings of disclosure items). We only focus on disclosure items from different standards relating to one particular asset. Thus, equal weighting of standards is not relevant for the purposes of this study.
} 
the corporate trade-off in a given country between non-disclosure and the proprietary costs the company faces by disclosing more.

In addition, we compute a third measure namely the Saidin index (DiscSaidin) (Hodgdon et al. 2008, 2009). As Hodgdon et al. (2009, p. 43) explain, this '...index weights each disclosure item by the percentage of firms in the sample that do not comply with the item'. We employ this alternative measure for two reasons. First, this measure treats all sample firms as a homogenous group (it is not country adjusted). Given that our sample firms are the largest in the EU and are constituents of the S\&P EU350 index, one could argue that they form more of a homogeneous group. Second, the primary assumption embodied in this measure is that less commonly disclosed items '... are more costly and may have greater informational value to financial analysts. Less common disclosures, therefore, receive a greater weighting in the Saidin index, with the weight approaching one for disclosures that no firm provides. Conversely, a disclosure that is less costly or onerous to provide and is provided by all firms would receive a weight closer to zero.' (Hodgdon et al. 2009, p. 43). Thus, the Saidin index can be used as a proxy for the proprietary related cost considerations arising from the preparation and dissemination of information that may influence managers' decisions. In line with this, this measure also reflects on the concept of materiality as defined by the IASB (i.e., information is material if its omission or misstatement could influence the economic decisions of users taken on the basis of the financial statements). Given that preparers do perceive these required disclosures as costly since they may provide proprietary information, a higher weight within the index is justified (considering that they go the extra mile and disclose more compared to others - hence they are subject to higher proprietary costs).

Before splitting the task of checking each firm in the sample against our checklists between ourselves, we apply the scoring process described above and we carry out a preliminary pilot study on ten randomly selected sample companies. Each one of us scores these ten firms 
independently. Using a Mann-Whitney test, we confirm that the differences in the compliance scores calculated independently are not statistically significant. This process enables us to ensure reliable scoring for all the firms in the sample between.

In line with Botosan (1997), once we compute the disclosure scores for all sample firms, we further assess their validity by testing their association with variables identified as significant determinants of compliance with mandatory disclosure requirements in prior relevant literature (i.e., Wallace et al. 1994, Ali et al. 2004, Glaum et al. 2013). The results from these tests confirm the validity of our disclosure measures as they are in line with the findings of this literature. See Appendix B for details around these tests.

\subsection{Cost of equity proxies}

Cost of equity measurement is extensively discussed in the literature. It can be calculated with the use of realised returns in an asset pricing model and/or be implied using expected cash flows and earnings (ICC). We focus on ICC, as realised returns are a noisy proxy for expected returns (e.g., Elton 1999, Fama and French 2002, Easton and Monahan 2016). ICC estimates expected returns directly from stock prices and cash flow forecasts without relying on biased realised returns or on asset pricing models (Hou et al. 2012). ICC estimates are based on variations of the Edwards-Bell-Ohlson accounting model (Edwards and Bell 1961, Ohlson 1995). A growing literature compares and assesses the accuracy, validity and reliability of various ICC proxies developed, resulting in various alternative ICC specifications (e.g., Botosan and Plumlee 2005, Easton and Monahan 2005, Pastor et al. 2008, Botosan et al. 2011).

As a result, many empirical studies use an average of various ICC models instead of using one (e.g., Francis et al. 2005, Hail and Leuz 2006, Daske et al. 2008, Muino and Trombetta 2009, Li 2010, Kim et al. 2012, Blanco et al. 2015). We follow this approach and use four different ICC measures, namely the measures of Claus and Thomas (2001) $\left(r_{C T}\right)$, Gebhardt et 
al. (2001) $\left(r_{G L S}\right)$, Gode and Mohanran (2003) $\left(r_{G M}\right)$, and Easton (2004) $\left(r_{M P E G}\right)$. Appendix C describes the properties of the four models we use.

\subsection{Multivariate analyses}

We test our hypotheses using the following regression model:

$$
r_{j t}=\beta_{0}+\beta_{1} \text { Disclos }_{j t}+\beta_{2} \sum \text { controls }_{j t}+\varepsilon_{j t}
$$

where $r$ is ICC based on the average of the four estimated ICC measures we compute and Disclos is DiscSaidin, DiscScaled or DiscRaw. Controls consist of factors that may be associated with ICC, including risk and country specific effects (see Botosan and Plumlee 2002, Hail 2002, Francis et al. 2005, Gietzmann and Ireland 2005, Francis et al. 2008, Daske et al. 2008, Li 2010), namely the level of goodwill in each firm's balance sheet i.e., percentage (\%) of goodwill on book value of equity $(G d w B V)$; the negative logarithmic transformation of the annual report page count (Readability) (Lawrence 2013); the absolute value of abnormal working capital accruals scaled by total assets (AWCA) (DeFond and Park 2001); the return on total assets $(R O A)$; the market value to book value of equity $(M 2 B)$; the total debt to book value of equity (Leverage); the natural logarithm of market value (Size); the return variance over the financial year (rVar); the EPS forecasts standard deviation (Dispersion); the market development, i.e., the market capitalisation of listed companies as a percentage of GDP for each country (MrktDev) (World Bank); and an index capturing the enforcement body's strength in each country by considering eight characteristics including its powers, activities, and resources (Enforcement) (Brown et al. 2014).

We perform OLS regression estimations using Eq. (2) where we include industry dummy variables based on ICB Level 2 industry classification. ${ }^{9}$ We also control for cross-sectional and

\footnotetext{
${ }^{9}$ We do not include country dummy variables since these are correlated with the proxies for country characteristics in our models. This approach is in line with Preiato et al. (2015).
} 
time series correlation by clustering by firm and year (Petersen 2009). A negative $b_{1}$ in Eq. (2) will indicate support of our first hypothesis. In an attempt to address the inherent endogeneity issue when looking at disclosure and the cost of capital (see Nikolaev and van Lent 2005, Larker and Rusticus 2010), we also perform a panel data year fixed effects estimation as a robustness test. ${ }^{10}$ For brevity, we do not tabulate these but we discuss differences in the results when these exist.

To test our second hypothesis, we first follow the Ramanna and Watts (2012) method to identify firms for which the market anticipates a goodwill impairment loss. We identify firms that have book to market (BTM) ratios lower than one at the end of year $t-2$ and retain only those for which BTM is higher than one at the end of year $t-1$. To minimise the likelihood that this BTM change is associated with other impairments, we also impose that BTM is higher than one at the end of year $t$. On that basis, if a firm is (not) expected to impair goodwill in a particular year and does (does not do) so, we categorise it as a firm that meets the market's expectations (i.e., MrktMet =1). If a firm is not (is) expected to impair goodwill in a particular year but it does (not do) so, we categorise it as a firm that does not meet the market's expectations (i.e., MrktMet $=0$ ). Having classified our sample firms in this way, we perform Eq. (2) in panel regression estimations across these two subsamples. We conjecture that disclosure levels for firms that do not meet the market expectations should matter more for investors. Therefore, higher disclosure within this sub-sample should reduce cost of equity capital more than that of

\footnotetext{
${ }^{10}$ Year fixed effects estimation differs from OLS with standard errors clustered by firm and year (Petersen, 2009). This is because the Petersen (2009) firm and year clustering controls for firm autocorrelation (i.e., it holds firms stable, waiving the correlation among standard errors for the same company) and also controls for time-series dependence of standard errors (i.e., it holds time stable, imposing time independent effects on the explanatory variables). On the other hand, year fixed effects estimation controls only for time-series dependence of the explanatory variables. In other words, OLS with standard errors clustered by firm and year controls for both time and cross-section correlation, whereas year fixed effects controls only for time-series correlation. Using both enhances the robustness of our findings.
} 
firms that do meet the market expectations. Our second hypothesis predicts a (more) negative $b_{1}$ in Eq. (2) for firms that do not meet the market's expectations.

\section{Results}

\subsection{Descriptive statistics}

Table 2 reports the extent to which sample firms comply with goodwill related mandatory disclosures during 2008-2011. Panel A shows descriptive statistics for the full sample. Mean (median) degree of compliance with goodwill related mandatory disclosure is relatively high, with a minimum of $77.8 \%(78.6 \%)$ in 2008 and a maximum of $85.7 \%(88.9 \%)$ in 2010 . Moreover, there are fully compliant firms in each year. To contextualise the importance of these findings, as shown in Table 4 below, the mean (median) ratio of goodwill to book value of equity for our sample firms is $70 \%(51 \%)$, indicating how material goodwill is for this set of firms. Nonetheless and consistent with prior studies (e.g., Al-Shammari et al. 2008, Al-Akra et al. 2010, Tsalavoutas 2011, Glaum et al. 2013), there exist important differences among firms' mandatory disclosure levels. The standard deviation is around $14 \%$ while minimum compliance levels are $33 \%$.

Panel B presents the results of a Cuzick (1985) test, a non-parametric test for trends across ordered groups. There is a significant positive trend in compliance scores from 2008 to 2011 ( $p$ $<0.01$ ) indicating that compliance scores improve over time. We also investigate this trend with a Mann-Whitney and a $T$-test for each pair of years tested and there is a statistically significant increase in compliance scores from 2008 to 2009 and from 2009 to 2010, while there is a slight decrease from 2010 to $2011(p<0.01)$. These results are also confirmed by Panel C: there are far more companies with $91 \%$ - 100\% compliance in 2011 compared to 2008 (70 vs. 29 firms respectively). Moreover, a much smaller number of companies with $31 \%-60 \%$ compliance exist in 2011 compared to 2008 (6 vs. 14 firms respectively). 
Overall, Table 2 shows an improvement of mean compliance levels over time. Nevertheless, a relatively large number of firms still fail to comply in full with the standards' requirements every year. This finding is consistent with the literature claiming that compliance with mandatory disclosure requirements is not 'sticky over time', because managers' decision on whether to comply with the requirements is discretionary and depends on the regulatory risk they face. Mean (median) levels of compliance among different countries are shown in Panel D. Consistent with prior empirical evidence (Glaum et al. 2013), we document that compliance levels with mandatory disclosures differ significantly across countries.

\section{TABLE 2 - ABOUT HERE}

Table 3 provides information regarding specific items mandated by IFRS 3 and IAS 36, which are applicable to more than 100 firm-year observations and for which high non-compliance (i.e., less than $90 \%$ compliance) is observed. We highlight noticeable observations.

To start with IFRS 3 (Panel A), although all our sample firms report a reconciliation of the carrying amount of goodwill at the beginning and the end of the period, a large portion of firms do not disclose the gross amount and accumulated goodwill impairment losses at the beginning of the period (only 79.8\% of firms for which sub-paragraphs 75-a-i and B67-d-i are applicable, comply with these requirements) or the end of the period (only $86.9 \%$ of firms for which $75-\mathrm{a}-$ viii and B67-d-viii are applicable, comply). This type of difference across firms is particularly important for the purposes of our study. Prior literature indicates that goodwill impairment losses result in negative valuation effects (Hirschey and Richardson 2002).

Moreover, we observe significant non-compliance with the item requiring information about the factors resulting in the recognition of goodwill for business combinations that were collectively material. Interestingly, the less prescriptive requirement in the revised paragraph B65-e seems to result in more firms complying (51.8\% of firms for which sub-paragraph B65e is applicable) compared to the more stringent requirement in paragraph 68-h in the old IFRS 
$3(9.1 \%$ of firms for which $68-\mathrm{h}$ is applicable). Yet, financial statement users indicate that this is one of the most important pieces of information they are concerned with around business combinations (FRC 2014). Further, only $65.4 \%$ of firms that conducted business combinations that were collectively material, report the amounts recognised as of the acquisition date for each major class of assets acquired and liabilities assumed, although investors attach valuation weights to the identifiable components of purchased goodwill (Henning et al. 2000). Overall, our findings regarding IFRS 3 suggest that investors are confronted with differences across firms in the level of information they consider important.

Turning to the disclosures mandated by IAS 36 (Panel B), most of the items with which companies do not comply relate to the estimations and assumptions used during the goodwill impairment testing process. For example, irrespective of whether companies use the value in use method or the fair value less cost to sell approach, a large proportion of them $(29 \%$ and $16 \%$ of firms for which 134-d-i and 134-e-i are applicable, respectively) do not disclose a description of each key assumption used by management to determine the recoverable amount. Similarly, a large proportion of firms (39\% and 42\% respectively) fail to disclose management's approach to determine the value(s) assigned to each key assumption (sub-paragraphs 134-d-ii and 134-e-ii). Not disclosing this information appears to confirm the concerns expressed about the quality of goodwill impairment tests (Hoogendoorn 2006, Carlin and Finch 2009, 2010) and the absence of an 'important input to users' assessment of the amount, timing, and uncertainty of (the prospect for) future net cash inflows to the entity (ASBJ et al. 2014, p. 41). Moreover, in relation to sub-paragraph 129 a, we identify a large proportion of companies (almost $30 \%$ of applicable firms) that recognise a material goodwill impairment loss but do not disclose the amount of this loss across each reportable segment. These findings confirm the views expressed by financial statement preparers that they are somewhat reluctant to disclose this type of information as they consider it proprietary (ASBJ et al. 2014). Hence, it appears that a large 
number of firms do not provide important information to the market that is considered to be private (Bens et al. 2011, Li et al. 2011). Finally, compliance with the requirements of subparagraph 134-f is also problematic. This item requires information related to a reasonably possible change in a key assumption that management has based its determination of the unit's (group of units') recoverable amount which would cause the carrying amount to exceed its recoverable amount.

Overall, the compliance levels with the items in Table 3 are indicative of differences across firms in the level of firm-specific information that reaches financial statement users. This list reveals areas within individual IFRS that may need to be addressed by the standard setter in order to provide guidance on how these should be interpreted and applied.

TABLE 3 - ABOUT HERE

\subsection{Univariate analysis}

Table 4 reports descriptive statistics for the dependent and independent variables used in the multivariate analyses. ${ }^{11}$ Panel A shows information about country- and firm-level independent variables, including the disclosure scores. Mean (median) disclosure is $0.614(0.467), 0.275$ (0.257) and $0.564(0.555)$ when the disclosure score is DiscScaled, DiscRaw or DiscSaidin respectively. There is considerable variation in these metrics; standard deviation is high $(0.556$, 0.179 and 0.253 , respectively). In fact, the variation is such that in some countries some firms disclose twice as much information than others (maximum DiscScaled is 2.00).

As mentioned, goodwill is a large part of the equity book value for our firms with mean (median) $G d w B V$ equal to 0.699 (0.507). Mean (median) market value of equity $(M V)$ is 15.6 (7.3) billion euros. These high values are expected given that our sample firms are drawn from

\footnotetext{
${ }^{11}$ For Size and Readability we use transformations of market value (MV) and annual report page numbers (PageCount) in the univariate and multivariate analyses. For a better understanding of Size and Readability, though, we present their actual data of $M V$ and PageCount without transformations in Table 4.
} 
the S\&P EU350 i.e., among the largest and most liquid stocks in Europe. Mean (median) market to book value $(M 2 B)$ is $2.7(1.9)$. The complexity of annual reports (as proxied by the number of pages) varies significantly across our sample firms: mean (median) number of pages is 200 (179) with a maximum of 620 and a minimum of 54. On average, the sample firms are profitable (mean (median) ROA is $0.048(0.044)$ ), while debt-to-equity (Leverage) is $1.153(0.71)$.

In terms of country-level variables, the maximum value of MrktDev (i.e., market capitalisation to GDP) is 2.3 , which relates to Switzerland. All other data are below 1, apart from that related to the UK and Sweden for 2009 and 2010. High variation in enforcement mechanisms among the countries investigated is also evident.

Panel B gives descriptive statistics regarding our ICC measure $\left(r_{A V}\right)$ for the full sample and for each year. Mean (median) $r_{A V}$ varies from a minimum of $10.5 \%(10.4 \%)$ in 2010 to a maximum of $11.8 \%(10.9 \%)$ in 2011 , showing also variation in the ICC during the period examined. Overall, mean (median) $r_{A V}$ is $11.1 \%(10.6 \%)$, while the standard deviation is $4 \%$. Panel C presents Cuzick test for trends, documenting no statistically significant trends in the ICC through the period examined. The Mann-Whitney test and the T-test report a statistically significant increase in ICC only from 2010 to 2011. Given that we employ an average measure, Panel D gives Pearson's correlation coefficients across the different ICC models we use. All models are positively correlated and statistically significant $(p<0.01)$, suggesting that all four ICC measures capture similar information and our average ICC is robust.

\section{TABLE 4 - ABOUT HERE}

Pearson's correlation coefficients between all variables are presented in Table 5. As one would expect, our three disclosure proxies (DiscScaled, DiscRaw and DiscSaidin) correlate highly positively with each other $(p<0.01)$. Consistent with our hypotheses, this preliminary evidence shows that there is a negative and statistically significant correlation between the ICC and 
compliance with mandatory disclosure requirements: DiscScaled, DiscRaw and DiscSaidin document a correlation coefficient of $-0.141,-0.139$ and $-0.103(p<0.01)$, respectively.

Country-adjusted compliance scores (DiscScaled and DiscRaw) are positively correlated with the percentage of goodwill to equity book value $(G d w B V)$ with a correlation coefficient near to $0.150(p<0.01)$. DiscSaidin, which is not country-adjusted, is not significantly correlated with $G d w B V$. These imply that the higher the goodwill, the more the goodwill related mandatory information a firm tends to disclose at a country level, but not across the sample firms as a whole. This indicates that country characteristics are indeed important and could affect managerial discretion towards the decision making process (which is affected by regulatory risk) on whether a firm will comply with disclosure requirements. Consistent with this, the coefficients of both country specific variables, enforcement and market development (MrketDev), are positive (negative) and highly correlated (statistically significant at the $1 \%$ level $(p<0.01))$ with all disclosure scores (ICC proxied by $r_{A V}$ ). Hence, the stronger the enforcement in a country and the more developed the market is the higher the levels of goodwill related mandatory disclosure communicated to the market. Further, the stronger the enforcement and the more developed the market, the lower the ICC. Moreover, compliance levels are positively correlated with analyst forecast dispersion, indicating that higher compliance brings new information to the market, leading analysts to 'disagree' regarding future firm performance. Additionally, Size, profitability $(R O A)$ and growth $(M 2 B)$ are negatively correlated with ICC, while Leverage, return variance (rVar) and abnormal accruals (AWCA) have a positive relationship (all significant at 5\% and $1 \%$ levels). Finally, the relationship between Size and Readability is negative, consistent with prior literature showing that larger firms have longer and more complex annual reports (Li 2010).

TABLE 5 - ABOUT HERE 
Regarding our second hypothesis, we identify 570 (13) firm-year observations for which the market did not expect (expected) recognition of a goodwill impairment loss and these companies did not recognise (recognised) an impairment loss, as expected. We classify these 583 firm-year observations as companies that meet the market expectations with regard to the recognition of goodwill impairment loss $($ MrktMet $=1)$. In contrast, we identify 235 (13) firmyear observations for which the market did not expect (expected) recognition of a goodwill impairment loss but these companies did (did not) recognise, thus, failing to meet expectations. We classify these 248 firm-year observations as companies that do not meet these market expectations $($ MrktMet $=0)$.

Table 6 provides relevant descriptive statistics. Firms that meet the market expectations $($ MrktMet $=1)$ have higher country-adjusted disclosure scores (DiscScaled and DiscRaw) and lower ICC $\left(r_{A V}\right)$ than firms that do not. The mean and median differences are statistically significant at least at the 5\% level. Firms meeting market expectation seem, on average, to provide much higher disclosure levels than their country minimums. Additionally, they experience a lower ICC compared to the firms not meeting market expectations. These firms also have statistically significant higher profitability $(R O A)$ and market-to-book $(M 2 B)$ ratios i.e., have higher growth opportunities. They also operate in countries with more developed stock markets and higher enforcement, compared to the firms that do not meet the market expectations. On the other hand, firms in this group have lower goodwill-to-book value of equity $(G d w B V)$, statistically significantly fewer material impairment losses (MaterialIL), and less material business combinations (MaterialBC), compared to the firms that do not meet the market expectations $(M r k t M e t=0)$. These descriptive statistics indicate that the two subsamples are substantially different (e.g., growth, location, performance), allowing us to infer that they share different levels of information risk. Firms that do not meet the market expectations about recognition of a goodwill impairment loss are significantly riskier. 
TABLE 6 - ABOUT HERE

\subsection{Multivariate analysis}

Table 7 presents our main findings. With regard to H1, results show that disclosure is negatively (coefficients for DiscSaidin, DiscScaled and DiscRaw are $-0.011,-0.007$ and -0.020 respectively) and statistically significantly associated with ICC $(p<0.05)$.

Regarding the remaining variables, Size and profitability $(R O A)$ are negatively associated with ICC (significant at least at the 5\% level). Companies experience lower ICC in more developed markets (MrktDev) and in countries with better enforcement mechanisms (Enforcement). Additionally, Readability is negatively associated with ICC $(\mathrm{p}<0.10)$, suggesting that more concise annual reports result in a reduction in ICC, in line with Lawrence (2013). Under the year fixed effects estimation, MrktDev, Enforcement and Readability are not statistically significant. Instead, higher dispersion in analysts' forecasts is associated with higher ICC (at the 10\% level). This is in line with Francis et al. (2005) and Li (2010). Leverage is negatively associated with ICC $(\mathrm{p}<0.05)$.

\section{TABLE 7 - ABOUT HERE}

These results support our first hypothesis that compliance with goodwill related mandatory disclosures have a negative association with ICC and contribute to the disclosure literature by providing some evidence about the economic consequences of disclosures mandated by accounting standards (Leuz and Wysocki 2016). IFRS 3 disclosures (e.g., provision of information on purchase price allocation, amount of goodwill (positive/negative) arising from business combinations, and a description of factors that make up the goodwill recognised) and IAS 36 disclosures (e.g., provision of information relating to the allocation of existing goodwill to CGUs and estimation of its recoverable amount, along with information including cash flow projection periods, growth rates, discount rates and events/circumstances that lead to impairment loss recognition) contribute to a reduction of estimation risk. 
These disclosures enable financial statement users to gather information about a firm's private information (Dye 1985), reducing uncertainty about forecasted earnings (Hope 2003) and estimation risk and improving information precision (Barry and Brown 1985, Hughes et al. 2007, Lambert et al. 2007, 2012). When managers comply with the relevant mandated items (see Table 3), managerial private information becomes observable and verifiable by external stakeholders (Riedl 2004). Overall, our findings are in line the estimation risk/information precision theory.

Our results also support our second hypothesis that compliance with goodwill related disclosures is indeed negatively associated with ICC. This link, however, is apparent only for firms not meeting the market expectations $(M r k t M e t=0)$. Results show that the coefficients for DiscSaidin, DiscScaled and DiscRaw are $-0.016,-0.022$ and -0.054 , respectively. The coefficients are statistically significant at the 5\% level at least. With regard to the remaining factors, irrespective of the specification and sub-sample, profitability $(R O A)$ is associated negatively with ICC. Overall, higher disclosures for firms that do not meet the market expectations matter for investors. A firm that recognises a goodwill impairment loss when not expected to do so (and vice versa) surprises investors, triggering them to revise their estimation risk of that firm. Thus, the level of goodwill related mandatory disclosure appears to have an important role in shedding light on why the firm goes against expectations and helps in revising future earnings and cash flows.

Reflecting on our findings in Table 3, firms tend not to comply with items beneficial for investors in confirming their prior anticipation of a goodwill impairment loss. Thus, firms providing unexpected (or new) information to the market and at the same time providing more information compared to similar firms, benefit from a reduction in ICC. These results are also supportive of the above theory. 


\subsection{Additional tests - the interplay between enforcement and estimation risk}

The accounting literature widely documents that enforcement is a fundamental characteristic of the financial reporting environment in a country. Not only does it play a crucial role in the level of quality of financial statements themselves, but also on how market participants react to accounting information. With regard to the former, cross-country studies report a negative association between earnings management and enforcement strength (e.g., Leuz et al. 2003, Burgstahler et al. 2006, Callao and Jarne 2010). With regard to disclosures, Glaum and Street (2003) and Aerts and Tarca (2010) reach similar conclusions in that there is a positive association between disclosure behaviour and country enforcement. More relevant to our study, Glaum et al. (2013) report a positive association between country enforcement strength and compliance with mandatory disclosure requirements and Hope (2003) finds that firm's annual report disclosure level is positively associated with forecast accuracy, with this being more prevalent in countries where enforcement is stronger. Daske et al. (2008) find capital-market benefits to be associated with mandatory adoption of IFRS only in countries where firms have incentives to be transparent and where legal enforcement is strong. Along similar lines, Armstrong et al. (2010) find an incrementally negative stock market reaction for firms domiciled in code law countries compared to common law countries and attribute this to investors' concerns over IFRS enforcement in these countries. Finally, Byard et al. (2011) find that the effects of mandatory IFRS adoption on forecast errors and forecast dispersion depend on the level of enforcement in the country of adoption. These studies conclude that even though IFRS are considered to be of higher quality than local accounting standards, financial reporting quality depends on enforcement. 
We reflect on this issue by splitting our sample across countries with high vs low enforcement (based on the country median enforcement level). ${ }^{12}$ The results of these tests are provided in Tables 8 and 9.

\section{TABLE 8 ABOUT HERE}

\section{TABLE 9 ABOUT HERE}

With regard to $\mathrm{H} 1$, we find that only for the sub-sample of companies in countries with high enforcement are the coefficients for DiscSaidin, DiscScaled and DiscRaw negative and significant $(-0.013$ at the $10 \%$ level, -0.010 at the $5 \%$ level and -0.029 at the $5 \%$ level, respectively). With regard to $\mathrm{H} 2$, higher compliance for firms that do not meet the market expectations matter for investors only if these firms operate in a country with strong enforcement. $^{13}$

These findings are not surprising. First, there are much higher compliance levels and a much higher deviation of these levels within the sub-sample of firms in countries with high enforcement. Untabulated descriptive statistics reveal that DiscSaidin, DiscScaled and DiscRaw scores are $0.62,0.66,0.29$ respectively, compared to $0.48,0.54,0.25$ for the corresponding subsample of companies in countries with low enforcement. Further, these differences are significant at the $1 \%$ level. When analysts/investors follow firms in an environment with high enforcement they are able to evaluate the information around goodwill and its impairment testing process given that, by definition, a lot of the relevant information is present/disclosed. Thus, firms with relatively lower compliance levels in such an environment are penalised with higher ICC and vice versa. On the contrary, in an environment where enforcement is low, the lack of information in the notes of the financial statements is significant/material and analysts/investors are unable to evaluate the information around goodwill and its impairment

\footnotetext{
${ }^{12}$ It is also noted that enforcement is positively associated with the non-country adjusted scores compliance scores (see Appendix B).

${ }^{13}$ All corresponding coefficients under fixed effects estimations are negative but not statistically significant.
} 
testing process. Thus, variation in the (low) compliance levels is not associated with different levels of ICC. Second, these findings are partly in line with those in Abdullah et al. (2015) in that, in countries where enforcement is weak, compliance levels with mandatory disclosure requirements are not relevant to investors. Demand for public information is low and information is usually disseminated via private communication channels instead (Ball et al. 2003).

\section{Sensitivity analyses}

Although our compliance scores take into account the number of applicable items that should be disclosed, if a company recognises an immaterial goodwill impairment loss, disclosure of information with regard to two additional items in our index is triggered. When a company recognises a material goodwill impairment loss, disclosure of information with regard to six or seven items in our index is triggered (depending on whether the recoverable amount is estimated with value in use, fair value, or both). Thus, goodwill related mandatory disclosures may be higher because of recognising an impairment loss. To ensure our results are driven by the level of compliance and not the loss itself, we perform the following tests: 1) we exclude the firms with material impairment losses of goodwill; 2) we incorporate a dummy variable capturing the occurrence of material goodwill impairments as another control in our tests; and 3) we add a dummy variable capturing the occurrence of an impairment loss (without separating into material and immaterial) as another control in our main tests. In all these cases, results are qualitatively similar.

We also repeat our analysis for $\mathrm{H} 1$ after splitting the sample into high vs. low compliant countries, based on the sample median compliance score. Our results are similar to those we obtain for H1 when we split the sample across high vs. low enforcement. We are unable to run these tests for $\mathrm{H} 2$ due to the low number of observations across sub-samples. 
Further, given the debate surrounding the validity of ICC measures, we rerun our regressions by using a single ICC measure i.e., the $r_{M P E G}$ (Easton 2004). Clarkson et al. (2013) suggest that $r_{M P E G}$ is best for ICC measures employing analyst forecasts. Although these tests reduce our sample from 831 to 785 firm-year observations, the results are almost identical to those in the main analysis. We additionally follow Muino and Trombetta (2009), Li (2010) and Kim et al. (2012) and use an average ICC for which we have estimates for all four measures. Again, the sample drops (from 831 to 635 firm-year observations) but results are qualitatively similar in that the two country-adjusted scores are significantly associated with ICC (but not DiscSaidin) when examining $\mathrm{H} 1$, and the results for all compliance scores are statistically significant, albeit at the $10 \%$ level, when examining $\mathrm{H} 2$.

Moreover, similar to Francis et al. (2008) and Muino and Trombetta (2009), we calculate ex-post cost of capital. We run firm-specific asset pricing models where the theoretical Capital Asset Pricing Model (CAPM) is augmented with a disclosure factor. ${ }^{14}$ The average firm beta is positive and statistically significant at the $1 \%$ level as expected. The average coefficient of the disclosure factor, however, is not statistically significant, consistent with Muino and Trombetta (2009), so H1 is not supported when we replicate our main analyses. Interestingly though, when testing $\mathrm{H} 2$, compliance continues to be negatively and statistically significantly associated with the cost of equity capital when the market's expectations are not met. Thus, although we do not expect strong results because of the different nature of these models and their reduced power, we still find significant results for the sub-sample of firms not meeting the market's

\footnotetext{
${ }^{14}$ The use of realised returns for calculating the cost of equity capital, by definition, implies the use of ex-post information. Thus, it does not capture the same information as ICC. Using the CAPM may incorporate less noisy figures than other models, however CAPM assumes that cross-sectional variation in market beta drives variation in the cost of capital (Botosan 1997) and there is no theoretical room for disclosure or expectation that disclosure should affect the market beta. To construct our disclosure factor, we split the sample into two groups i.e., firms with high vs. low disclosure, based on the annual median compliance score. We calculate monthly returns for each firm, starting from June $t+1$ to May $t+2$. The high and low disclosure portfolios are reformed on an annual basis to create a low-minus-high ( $\mathrm{LMH}$ ) mimicking factor portfolio by subtracting the average monthly return of the low-disclosure portfolio minus that of the high-disclosure portfolio.
} 
expectations. These results are robust when the disclosure factor is constructed with all the different disclosure scores and also when we use an augmented version of the Fama and French (1993) model, instead of the CAPM.

Finally, we calculate an alternative disclosure metric, where we transform the actual disclosure scores in a percentile rank based on the actual scores of all sample firms on an annual basis, as in Botosan and Plumlee (2002), Nikolaev and van Lent (2005), and Glaum et al. (2013). Ranked variables are less sensitive to outliers (Cooke 1998) and have a normal distribution (McCabe 1989). We rerun our main analysis and results are again qualitatively similar, supporting both of our hypotheses. Hence, even when compliance scores are not country specific and there is no weighting of the items included in the disclosure lists, as in the case of the Saidin index, results still hold.

\section{Conclusions}

Looking at a set of non-financial firms members of the S\&P Europe 350 over a four-year period (2008-2011), we manually compute compliance with mandated goodwill disclosure from the notes of their financial statements. We first examine whether the level of compliance with the disclosure requirements is associated with firms' ICC. We then take a step further and question the channel through which compliance is associated with ICC and investigate whether, and the extent to which, compliance levels have a differential association with ICC across sub-samples of companies that meet (or not) market expectations about the recognition of goodwill impairment losses. In our setting, differences across firm compliance with disclosure requirements reflect the trade-off between firm litigation costs resulting from non-disclosure (Skinner 1994) and proprietary costs resulting from disclosure of the information required by IAS 36 and IFRS 3. We argue that, in line with information precision/ estimation risk theory (Barry and Brown 1985, Hughes et al. 2007, Lambert et al. 2007, 2012), goodwill disclosures allow for a better understanding of future earnings and cash flows. They should lead to a 
reduction in estimation risk since they are specifically related to information about timing, amount and risk of future cash flows.

Our results indicate significant differences in compliance levels with goodwill related disclosure requirements. We find a high variation in compliance levels with items that provide proprietary information and reveal management judgment and expectations (e.g., assumptions and estimations used in the application of value in use calculations; the amounts of impairment losses across reportable segments, and a qualitative description of the factors that make up the goodwill recognised in business combinations). Companies that exhibit higher compliance levels with these items benefit from a lower ICC (i.e., we find a negative association between compliance levels and ICC). Further, our results indicate that firms not meeting the market expectations with regard to goodwill impairment losses are significantly different from the remaining firms. They are, in fact, riskier compared to firms that meet the market's expectations. Additionally, we find robust evidence that compliance levels with goodwill related disclosures requirements are negatively associated with ICC only when firms do not meet the market's expectations. This supports our argument that increased levels of these disclosures mitigate estimation risk. The riskier firms do not meet the market's expectations causing a surprise to the market, which seeks additional information through these disclosures. To the best of our knowledge, prior relevant analysis and evidence is absent in this regard. Finally, these results hold only in countries with high enforcement, highlighting the complementary role of enforcement for benefits arising from high quality reporting.

Our findings, which add knowledge with regard to the economic consequences of disclosures mandated by accounting standards, should be appealing to regulators and financial statement preparers, and inform the current debate such as the IASB Disclosure Initiative and the FRC Disclosure Framework. We provide evidence that information disclosed in companies' financial statements as a result of the requirements of relevant standards is associated with ICC. 
This evidence could, arguably, assist in the development of more evidence-informed accounting standard-setting (Teixeira 2014).

Our study is subject to caveats. Despite following all usual procedures to ensure the validity and reliability of our research instrument, the use of a disclosure index always entails a degree of subjectivity. This may hinder consistent replication of the research. Further, how one defines materiality can be an important limitation of studies like ours. To align our research with the perception of enforcers on this issue, however, we follow the materiality threshold identified by ESMA in its 2013 review of impairment of goodwill and other intangible assets in the IFRS financial statements of 235 companies for 2011. Nevertheless, as we show in Table 3, many of the items for which we identify non-compliance are somewhat less subject to a materiality threshold. Additionally, the compliance levels we identify are in line with prior literature focusing in particular on this type of disclosures. Hence, even if one argues that our thresholds are not perfect, we believe that they capture sufficiently the variation in goodwill related mandatory disclosures that companies provide and users of financial statements consider important for their needs. Moreover, our sample excludes financial constituents of the S\&P EU 350. Given their size and importance in the European economies, their level of compliance with mandatory disclosures and corresponding potential consequences remain unexplored. We also acknowledge that caution is needed when interpreting our results due to potential endogeneity and/or econometric problems associated with the use of a non-country adjusted compliance score.

Future research could complement our study. Our sample firms are the most liquid and important non-financial European firms. Using a sample consisting of only financial and/or smaller non-financial firms may document different results. Finally, our study considers only one type of disclosure (i.e., goodwill related mandatory disclosure). Future studies could consider other aspects of disclosures mandated by accounting standards. 


\section{References}

Abdullah, M., Evans, L., Fraser, I. and Tsalavoutas, I., 2015. IFRS Mandatory disclosures in Malaysia: the influence of family control and the value (ir)relevance of compliance levels. Accounting Forum, 39 (4), 328-348.

Accounting Standard Board of Japan (ASBJ), European Financial Reporting Advisory Group (EFRAG) and Organismo Italiano di Contabilità (OIC), 2015. Should goodwill still not be amortised? Available from: http://www.efrag.org/files/Goodwill\%20Impairment $\% 20$ and\%20Amortisation/140725_Should_goodwill_still_not_be_amortised_Research _Group_paper.pdf [Accessed 8 June 2015]

Adams, G., 1994. What is compliance? Journal of Financial Regulation and Compliance, 2 (4), 278-285.

Al Jifri, K. and Citron, D., 2009. The value-relevance of financial statement recognition versus note disclosure: Evidence from goodwill accounting. European Accounting Review, 18 (1), 123-140.

Al-Akra, M., Eddie, I. and Jahangir, A.M., 2010. The association between privatization and voluntary disclosure: Evidence from Jordan. Accounting and Business Research, 40 (1), $55-74$.

Ali, J.M., Ahmed, K. and Henry, D., 2004. Disclosure compliance with national accounting standards by listed companies in South Asia. Accounting and Business Research, 34 (3), 183-199.

Al-Shammari, B., Brown, P. and Tarca, A., 2008. An investigation of compliance with international accounting standards by listed companies in the Gulf Co-Operation Council member states. International Journal of Accounting, 43 (4), 425-447.

Anctil, R.M., Dickhaut, J., Kanodia, C. and Shapiro, B., 2004. Information transparency and coordination failure: theory and experiment. Journal of Accounting Research, 42 (2), 159-195.

André, P., Filip, A. and Paugam, L., 2015. The effect of mandatory IFRS adoption on conditional conservatism in Europe. Journal of Business Finance \& Accounting, 42, 482514.

Armstrong C.S., Barth M.E., Jagolinzer A.D. and Riedl E.J., 2010. Market Reaction to the Adoption of IFRS in Europe. The Accounting Review, 85 (1), 31-61.

Artiach, T.C. and Clarckson, P.M., 2011. Disclosure, conservatism and the cost of equity capital: A review of the foundation literature. Accounting and Finance, 51(1), 2-49.

Ayers, B.J., Schwab, C.M. and Utke, S., 2015. Noncompliance with mandatory disclosure requirements: The magnitude and determinants of undisclosed permanently reinvested earnings. Accounting Review, 90 (1), 59-93.

Baiman, S. and Verrecchia, R.E., 1996. The relation among capital markets, financial disclosure, production efficiency, and insider trading. Journal of Accounting Research, 34 (1), 1-22.

Ball, R., Robin, A. and Wu, J.S., 2003. Incentives versus standards: Properties of accounting income in four East Asian countries. Journal of Accounting and Economics, 36(2), $235-$ 270.

Barry, C. and Brown, S., 1985. Differential information and security market equilibrium. Journal of Financial and Quantitative Analysis, 20 (4), 407-422.

Barth, M. and Clinch, G., 1996 International accounting differences and their relation to share prices: Evidence from U.K., Australian, and Canadian firms. Contemporary Accounting Research, 13 (2), 135-170.

Barth, M. and Israeli, D., 2013. Disentangling mandatory IFRS reporting and changes in enforcement. Journal of Accounting and Economics, 56(2-3), 178-188. 
Barth, M., Konchitchki, Y. and Landsman, W., 2013. Cost of capital and earnings transparency. Journal of Accounting and Economics, 55 (2-3), 206-224.

Bens, D., Heltzer, W. and Segal, B., 2011. The information content of goodwill impairments and SFAS 142. Journal of Accounting, Auditing and Finance, 26 (3), 527-555.

Bertomeu, J. and Cheynel, E., 2016. Disclosure and the cost of capital: A survey of the theoretical literature. Abacus, 52(2), 221-258.

Beyer, A., Cohen, D.A., Lys, T.Z. and Walther, B.R., 2010. The financial reporting environment: Review of the recent literature. Journal of Accounting and Economics, 50 (2-3), 296-343.

Blanco, B., Garcia Lara, J.M. and Tribo, J.A., 2015. Segment disclosure and cost of capital. Journal of Business Finance \& Accounting, 42(3\&4), 367-411.

Botosan, C. and Plumlee, M., 2002. A re-examination of disclosure levels and expected cost of equity capital. Journal of Accounting Research, 40 (1), 21-40.

Botosan, C. and Plumlee, M., 2005. Assessing alternative proxies for the expected risk premium. Accounting Review, 80 (1), 21-53.

Botosan, C., 1997. Disclosure level and the cost of equity capital. Accounting Review, 72 (3), 323-349.

Botosan, C., 2006. Disclosure and the cost of equity capital: What do we know? Accounting and Business Research, International Accounting Policy Forum, 31-40.

Botosan, C., Plumlee, M. and Wen, H., 2011. The relation between expected returns, realized returns, and firm risk characteristics. Contemporary Accounting Research, 28 (4), 1085 1122.

Brown, P., Preiato, J. and Tarca, A., 2014. Measuring country differences in enforcement of accounting standards: an audit and enforcement proxy. Journal of Business Finance \& Accounting, 41(1-2), 1-52.

Buijink, W., 2006. Evidence-based financial reporting regulation. ABACUS, 42(3-4), 296301.

Burgstahler, D. C., Hail, L. and Leuz, C., 2006. The importance of reporting incentives: Earnings management in European private and public firms. The Accounting Review, 81(5), 983-1016.

Bushee, B. and Leuz, C., 2005. Economic consequences of SEC disclosure regulation: Evidence from the OTCBB. Journal of Accounting and Economics, 39 (2), 233-264.

Byard, D., Li, Y. and Yu, Y., 2011. The effect of mandatory IFRS adoption on financial analysts' information environment. Journal of Accounting Research, 49(1), 69-96.

Callao, S. and Jarne, J.I., 2010. Have IFRS affected earnings management in the European Union. Accounting in Europe, 7(2), 159-189.

Camfferman, K. and Cooke, T., 2002. An Analysis of Disclosure in the Annual Reports of UK and Dutch Companies. Journal of International Accounting Research, 1(1), 3-30

Carlin, T.M. and Finch, N., 2009. Discount rates in disarray: Evidence on flawed goodwill impairment testing. Australian Accounting Review, 19 (4), 326-336.

Carlin, T.M. and Finch, N., 2010. Resisting compliance with IFRS goodwill accounting and reporting disclosures - Evidence from Australia. Journal of Accounting \& Organizational Change, 6 (2), 260-280.

Chalmers, K., Clinch, G., Godfrey, J.M. and Wei, Z., 2012. Intangible Assets, IFRS and Analysts' Earnings Forecasts. Accounting \& Finance, 52(3), 691-721.

Chauvin, K.W. and Hirschey, M., 1994. Goodwill, profitability, and the market value of the firm. Journal of Accounting and Public Policy, 13 (2), 159-180.

Clarkson, P., Fang, X., Li, Y., Richardson, G., 2013. The relevance of environmental disclosures: Are such disclosures incrementally informative? Journal of Accounting and Public Policy, 32 (5), 410-431. 
Clarkson, P., Guedes, J. and Thompson, R., 1996. On the diversification, observability and measurement of estimation risk. Journal of Financial and Quantitative Analysis, 31 (1), 69-84.

Claus, J. and Thomas, J., 2001. Equity premia as low as three percent? Evidence from analysts' earnings forecasts for domestic and international stock markets. Journal of Finance, 56 (5), 1629-1666.

Coles, J., Loewenstein, U. and Suay, J., 1995. On equilibrium pricing under parameter uncertainty. Journal of Financial and Quantitative Analysis, 30 (3), 347-374.

Cooke, T., 1992. The impact of size, stock market listing and industry type on disclosure in the annual reports of Japanese listed corporations. Accounting and Business Research, 87 (22), 229-237

Cooke, T., 1998. Regression analysis in accounting disclosure studies. Accounting and Business Research, 28 (3), 209-224.

Cuzick, J., 1985. A Wilcoxon-type test for trend. Statistics in Medicine, 87 (4), 87-89.

Daske, H., Hail, L., Leuz, C. and Verdi, R., 2008. Mandatory IFRS reporting around the world: Early evidence on the economic consequences. Journal of Accounting Research, 46 (5), 1085-1142.

De Fond, M. and Park, C., 2001. The reversal effect of abnormal accruals and the market valuation of earnings surprises. Accounting Review, 76 (3), 375-404.

Dhaliwal, D.S., Krull, L. and Li, O., 2007. Did the 2003 Tax Act reduce the cost of equity capital? Journal of Accounting and Economics, 43 (1), 121-150.

Dhaliwal, D.S., Li, O.Z., Tsang, A. and Yang, Y.G., 2011. Voluntary Non-Financial Disclosure and the Cost of Equity Capital: The Initiation of Corporate Social Responsibility Reporting, The Accounting Review, 86(1), 59-100.

Diamond, D. and Verrecchia, R.E., 1991. Disclosure, liquidity, and the cost of capital. Journal of Finance, 46 (4), 1325-1359.

Dugar, A. and Nathan, S., 1995. The effect of investment banking relationships on financial analysts' earnings forecasts and investment recommendations. Contemporary Accounting Research, 12 (1), 131-160.

Dye, R.A. and Sridhar, S.S., 2008. A positive theory of flexibility in accounting standards. Journal of Accounting and Economics, 46 (2-3), 312-333.

Dye, R.A., 1985. Strategic accounting choice and the effect of alternative financial reporting requirements. Journal of Accounting Research, 23 (2), 544-574.

Dye, R.A., 1986. Proprietary and non-proprietary disclosures. Journal of Business, 59(2), 331-336.

Easley, D. and O'Hara, M., 2004. Information and the cost of capital. Journal of Finance, 59 (4), 1553-1583.

Easton, P. and Monahan, S., 2005. An evaluation of the reliability of accounting based measures of expected returns: A measurement error perspective. Accounting Review, 80 (2), 501-538.

Easton, P. and Sommers, G., 2007. Effect of analysts' optimism on estimates of the expected rate of return implied by earnings forecasts. Journal of Accounting Research, 45 (5), 983 1015.

Easton, P., 2004. PE ratios, PEG ratios, and estimating the implied expected rate of return on equity capital. Accounting Review, 79 (1), 73-96.

Easton, P.D and Monahan, S.J, 2015. Review of Recent Research on Improving Earnings Forecasts and Evaluating Accounting-based Estimates of the Expected Rate of Return on Equity Capital, ABACUS, 52(1), 35-58.

Edwards, E. and Bell, P., 1961. The theory and measurement of business income. Berkeley: University of California Press. 
Elton, J., 1999. Expected return, realized return, and asset pricing tests. Journal of Finance, 54 (4), 1199-1220.

Ernst \& Young (EY), 2010. Meeting today's financial challenges - impairment reporting: Improving stakeholder confidence. Ernst \& Young publication, $24 \mathrm{p}$.

European Financial Reporting Advisory Group (EFRAG), 2012. Towards a Disclosure Framework for the Notes - Discussion paper. Available from http://www.efrag.org/files/ProjectDocuments/PAAinE\%20Disclosure\%20Framework/1 21015_Disclosure_Framework_-_FINAL1.pdf [Accessed 8 June 2015].

European Security and Markets Authority (ESMA), 2013. European enforcers review of impairment of goodwill and other intangible assets in the IFRS financial statements. Available from http://www.esma.europa.eu/system/files/2013-02.pdf [Accessed 8 June 2015].

Fama, E. and French, K R., 2002. The equity premium. Journal of Finance, 57 (2), 637-659.

Fama, E. and French, K., 1993. Common risk factors in the returns on stocks and bonds. Journal of Financial Economics, 33 (1), 3-56.

Financial Accounting Standards Board (FASB), 2015. Accounting for goodwill for public business entities and not-for-profit entities. Available from http://www.fasb.org/cs/ContentServer?c=FASBContent_C\&pagename=FASB\%2FFAS BContent_C\%2FProjectUpdatePage\&cid=1176163679475 [Accessed 8 June 2015]

Financial Reporting Council (FRC), 2012. Thinking about disclosures in a broader context. A road map for a disclosure framework. http:/www.efrag.org/files/ProjectDocuments/PAAinE\%20Disclosure\%20Framework/1 21015_Disclosure_Framework_-_FINAL1.pdf [Accessed 8 June 2015].

Financial Reporting Council (FRC), 2014. Investor views on intangible assets and their amortization. Available from https://www.frc.org.uk/OurWork/Publications/Accounting-and-Reporting-Policy/Research-Report-Investor-Viewson-Intangible-Asset.pdf [Accessed 8 June 2015]

Francis, J., Khurana, I.K. and Pereira, R., 2005. Disclosure incentives and effects on cost of capital around the world. Accounting Review, 80 (4), 1125-1162.

Francis, J., Nanda, D. and Olsson, P., 2008. Voluntary disclosure, earnings quality, and cost of capital. Journal of Accounting Research, 46 (1), 53-99.

Frankel, R.M. and Lee, C.M.C., 1999. Accounting diversity and international valuation. Available from http://papers.ssrn.com/sol3/papers.cfm?abstract_id=2658 [Accessed 8 June 2015].

Gebhardt, W., Lee, C. and Swaminathan, B., 2001. Towards an ex-ante cost of capital. Journal of Accounting Research, 39 (1), 135-176.

Gietzmann, M.B. and Ireland, J., 2005. Cost of Capital, Strategic Disclosures and Accounting Choice. Journal of Business Finance \& Accounting, 32 (9-10), 599-634.

Gietzmann, M.B. and Trombetta, M., 2003. Disclosure interactions: accounting policy choice and voluntary disclosure effects on the cost of raising outside capital. Accounting and Business Research, 33 (3), 187-205.

Glaum, M. and Street, D.L., 2003. Compliance with the disclosure requirements of Germany's new market: IAS versus US GAAP. Journal of international financial management and accounting, 14 (1), 64-100.

Glaum, M., Schmidt, P., Street, D.L. and Vogel, S., 2013. Compliance with IFRS3- and IAS36-required disclosures across 17 European countries: company- and country-level determinants. Accounting and Business Research, 43 (3), 163-204.

Gode, D. and Mohanram, P., 2003. Inferring the cost of capital using the Ohlson-Juettner model. Review of Accounting Studies, 8 (3), 399-431. 
Gordon, J. and Gordon, M., 1997. The finite horizon expected return model. Financial Analysts Journal, 53 (3), 52-61.

Gray, S.J., Radebaugh, L.H. and Robert, C.B., 1990. International perceptions of cost constraints on voluntary information disclosures: a comparative study of UK \& US multinationals. Journal of International Business Studies, 21 (4), 597-622.

Hail, L. and Leuz, C., 2006. International differences in the cost of equity capital: Do legal institutions and securities regulation matter? Journal of Accounting Research, 44 (3), 485-531.

Hail, L., 2002. The Impact of Voluntary Corporate Disclosures on the Ex Ante Cost of Capital for Swiss Firms. European Accounting Review, 11 (4), 741-743.

Harris, T. S., and S. Morsfield. 2012. An Evaluation of the Current State and Future of XBRL and Interactive Data for Investors and Analysts. Available from http://www4.gsb.columbia.edu/filemgr?\&file_id=7313156 [Accessed 8 June 2015]

Healy, P.M., Palepu, K.G. and Sweeney, A.H., 1999. Stock performance and intermediation changes surrounding sustained increases in disclosure. Contemporary Accounting Research, 16 (3), 485-520.

Henning, S.L., Barry, L.L. and Shaw, W.H., 2000. Valuation of the components of purchased goodwill. Journal of Accounting Research, 38 (2), 375-386.

Hirschey, M. and Richardson, V.J., 2002. Information content of accounting goodwill numbers. Journal of Accounting and Public Policy, 21 (3), 173-191.

Hodgdon, C., Tondkar, R., Adhikari, A. and Harless, D., 2009. Compliance with International Financial Reporting Standards and auditor choice: New evidence on the importance of the statutory audit. The International Journal of Accounting, 44 (1), 33-55.

Hodgdon, C., Tondkar, R., Harless, D. and Adhikari, W.A., 2008. Compliance with IFRS disclosure requirements and individual analysts' forecast errors. Journal of International Accounting, Auditing and Taxation, 17 (1), 1-13.

Hoogendoorn, M., 2006. International accounting regulation and IFRS implementation in Europe and beyond - Experiences with first-time adoption in Europe. Accounting in Europe, 3 (1), 23-26.

Hoogervorst, H. (2013). 'Breaking the boilerplate'. Available from http://www.ifrs.org/Alerts/Conference/Documents/2013/HH-Amsterdam-June2013.pdf, [Accessed 8 June 2015].

Hoogervorst, H., 2012. Speech on "The imprecise world of accounting" at the International Association for Accounting Education \& Research (IAAER) conference in Amsterdam. Available from http://www.ifrs.org/Alerts/Conference/Pages/HH-speech-AmsterdamJune-2012.aspx [Accessed 8 June 2015).

Hope, O.K., 2003. Accounting policy disclosure and analysts' forecasts. Contemporary Accounting Research, 20 (2), 295-321.

Hou, K., van Dijk, M.A. and Zhang, Y., 2012. The implied cost of capital: A new approach. Journal of Accounting and Economics, 53 (3), 504-526.

Hughes, J.S., Liu, J. and Liu, J., 2007. Information asymmetry, diversification, and cost of capital. Accounting Review, 82 (3), 705-729.

International Accounting Standard Board (IASB), 2013. Discussion Forum - Financial Reporting Disclosure. Feedback Statement. Available from http://www.ifrs.org/Alerts/PressRelease/Documents/2013/Feedback-Statement-

Discussion-Forum-Financial-Reporting-Disclosure-May-2013.pdf [Accessed 8 June 2015].

International Accounting Standard Board (IASB), 2015. Report and Feedback Statement Post-Implementation Review of IFRS3 Business Combinations. Available from 
http://www.ifrs.org/Current-Projects/IASB-Projects/PIR/PIR-IFRS-3/Documents/PIR_ IFRS\%203-Business-Combinations_FBS_WEBSITE.pdf [Accessed 8 June 2015].

Jenkinson, D., 1996. Compliance culture. Journal of Financial Regulation and Compliance, 4 (1), 41-46.

Jennings, R., Robinson, J., Thompson, R.B. and Duvall, L., 1996. The relation between accounting goodwill numbers and equity values. Journal of Business Finance and Accounting, 23 (4), 513-533.

Kim, O. and Verrecchia, R.E., 1994. Market liquidity and volume around earnings announcements. Journal of Accounting and Economics, 17 (1-2), 41-68.

Kim, Y., Li, H. and Li, S, 2012. Does eliminating the Form 20-F reconciliation from IFRS to U.S. GAAP have capital market consequences? Journal of Accounting and Economics, 53 (1-2), 249-270.

Knauer, T., and Wohrmann, A., 2015. Market reaction to goodwill impairments. European Accounting Review, 25 (3), 421-449.

KPMG, 2014. Who cares about goodwill impairment? A collection of stakeholder views. Available from http://www.kpmg.com/CN/en/IssuesAndInsights/ArticlesPublications/ Documents/Who-cares-about-goodwill-impairment-O-201404.pdf [Accessed 8 June 2015]

Lambert, R.A., Leuz, C. and Verrecchia, R.E., 2007. Accounting information, disclosure, and the cost of capital. Journal of Accounting Research, 45 (2), 385-420.

Lang, M. and Lundholm, R., 1993. Cross-sectional determinants of analyst ratings of corporate disclosures. Journal of Accounting Research, 31 (2), 246-271.

Larker, D.F. and Rusticus, T.O., 2010. On the use of instrumental variables in accounting research. Journal of Accounting and Economics, 49 (2), 186-205.

Lawrence, A., 2013. Individual investors and financial disclosure. Journal of Accounting and Economics, 56 (1), 130-147

Lee, C., 2011. The Effect of SFAS 142 on the Ability of Goodwill to Predict Future Cash Flows. Journal of Accounting and Public Policy, 30(3), 236-255.

Leuz, C. and Verrecchia, R.E., 2000. The economic consequences of increased disclosure. Journal of Accounting Research, 38 (supplement), 91-124.

Leuz, C. and Wysocki, P., 2016. The economics of disclosure and financial reporting regulation: Evidence and suggestions for future research. Journal of Accounting Research, 54 (2), 525-622.

Leuz, C., Nanda, D.J. and Wysocki, P.D., 2003. Earnings management and investor protection: An international comparison. Journal of Financial Economics, 69 (3), $505-$ 527.

Li, S., 2010. Does mandatory adoption of International Financial Reporting Standards in the European Union reduce the cost of equity capital? Accounting Review, 85 (2), 607-636.

Li, Z., Schroff, P.K., Venkataraman, R. and Zhang, I.V., 2011. Causes and consequences of goodwill impairment losses. Review of Accounting Studies, 16 (4), 745-778.

Lys, T.Z., Vincent, L. and Yehuda, N., 2012. The Nature and Implications of Acquisition Goodwill. http://ssrn.com/abstract=1802612 orhttp://dx.doi.org/10.2139/ssrn.1802612

Mahoney, P.G., 1995. Mandatory disclosure as a solution to agency problems. University of Chicago Law Review, 62 (3), 1047-1112.

Mazzi, F., Liberatore, G. and Tsalavoutas, I., (2016). Insights on CFOs perceptions about IAS 36 reporting. Accounting in Europe, http://dx.doi.org/10.1080/17449480.2016.1244341.

McCabe, B.P.M., 1989. Misspecification tests in econometrics based on ranks. Journal of Econometrics, 40 (2), 261-278.

McCarthy, M. and Schneider, D., 1995. Market perception of goodwill: some empirical evidence. Accounting and Business Research, 26 (1), 69-81. 
Muino, F. and Trombetta, M., 2009. Does graph disclosure bias reduce the cost of equity capital? Accounting and Business Research, 39 (2), 83-102.

Nikolaev, V. and Van Lent, L., 2005. The endogeneity bias in the relation between cost-ofdebt capital and corporate disclosure policy. European Accounting Review, 14 (4), 677 724.

Ohlson, J. and Juettner-Nauroth, B., 2005. Expected EPS and EPS growth as determinants of value. Review of Accounting Studies, 10 (2-3), 349-365.

Ohlson, J., 1995. Earnings, book value, and dividends in security valuation. Contemporary Accounting Research, 11 (2), 661-687.

Owusu-Ansah, S., 1998. The Impact of Corporate Attributes on the Extent of Mandatory Disclosure and Reporting by Listed Companies in Zimbabwe. The International Journal of Accounting, 33 (5), 605-631.

Pastor, L., Sinha, M. and Swaminathan, B., 2008. Estimating the Intertemporal Risk-Return Tradeoff using the Implied Cost of Capital, The Journal of Finance, 63(6), 2859-97.

Paugam, L., Astolfi, P. and Ramond, O., 2015. Accounting for business combinations: Do purchase price allocations matter? Journal of Accounting and Public Policy. 34 (4), 362391.

Petersen, M.A., 2009. Estimating standard errors in finance panel data sets: Comparing approaches, The Review of Financial Studies, 22(1), 435-480.

Pownall, G. and Schipper, K., 1999. Implications of accounting research for the SEC's consideration of International Accounting Standards for U.S. securities offerings. Accounting Horizons, 13 (3), 259-280.

Preiato, J., Brown, P. and Tarca, A., 2015. A comparison of between-country measures of legal setting and enforcement of accounting standards. Journal of Business Finance \& Accounting, 42 (1-2), 1-50.

Ramanna, K. and Watts, R.L., 2012. Evidence on the use of unverifiable estimates in required goodwill impairment. Review of Accounting Studies, 17(4), 749-780.

Richardson, A.J. and Welker, M., 2001. Social disclosure, financial disclosure and the cost of equity capital. Accounting, Organisations and Society, 26 (7-8), 597-616.

Riedl, E.J., 2004. An examination of long-lived asset impairment. Accounting Review, 79 (3), 823-852.

Robinson, J.R., Xue, Y. and Yu, Y., 2011. Determimants of disclosure noncompliance and the effect of the SEC review: Evidence from the 2006 mandated compensation disclosure regulations. Accounting Review, 86 (4), 1415-1444.

Skinner, D.J., 1994. Why firms voluntarily disclose bad news. Journal of Accounting Research, 32 (1), 38-60.

Teixeira, A., 2014. The International Accounting Standards Board and Evidence-Informed Standard-Setting. Accounting in Europe, 11 (1), 5-12.

Timmermann, A. 1993. How learning in financial markets generates excess volatility and predictability in stock prices. Quarterly Journal of Economics, 108 (4), 1135-1145.

Tsalavoutas, I., 2011. Transition to IFRS and compliance with mandatory disclosure requirements: What is the signal? Advances in Accounting, incorporating Advances in International Accounting, 27 (2), 390-405.

Tsalavoutas, I., Evans, L. and Smith, M., 2010. Comparison of two methods for measuring compliance with IFRS mandatory disclosure requirements. Journal of Applied Accounting Research, 11 (3), 213-228.

Verrecchia, R.E., 2001. Essays on disclosure. Journal of Accounting and Economics, 32 (13), 97-180. 
Wallace, R.S.O. and Naser, K., 1995. Firm-Specific Determinants of the Comprehensiveness of Mandatory Disclosures in the Corporate Annual Reports of Firms Listed on the Stock Exchange of Hong Kong. Journal of Accounting and Public Policy, 14 (4), 311-368.

Welker, M., 1995. Disclosure policy, information asymmetry, and liquidity in equity markets. Contemporary Accounting Research, 11 (2), 801-827. 
Appendix A - IFRSs disaggregation and disclosure items identification

\begin{tabular}{|c|c|c|}
\hline $\begin{array}{l}\text { STANDARD AND } \\
\text { PARAGRAPH }\end{array}$ & TEXT & $\begin{array}{c}\text { SCORE } \\
(\text { N.A. }-0-1) \\
\end{array}$ \\
\hline IAS36-p134 & $\begin{array}{l}\text { An entity shall disclose the information required by (a)-(f) for } \\
\text { each cash-generating unit (group of units) for which the } \\
\text { carrying amount of goodwill or intangible assets with } \\
\text { indefinite useful lives allocated to that unit (group of units) is } \\
\text { significant in comparison with the entity's total carrying } \\
\text { amount of goodwill or intangible assets with indefinite useful } \\
\text { lives: }\end{array}$ & APP. - N.A. \\
\hline IAS36-p134-d & $\begin{array}{l}\text { if the unit's (group of units') recoverable amount is based on } \\
\text { value in use: }\end{array}$ & APP. - N.A. \\
\hline IAS36-p134-d-i & $\begin{array}{l}\text { a description of each key assumption on which management } \\
\text { has based its cash flow projections for the period covered by } \\
\text { the most recent budgets/forecasts. Key assumptions are those } \\
\text { to which the unit's (group of units') recoverable amount is } \\
\text { most sensitive. }\end{array}$ & $0-1$ \\
\hline IAS36-p134-d-ii & $\begin{array}{l}\text { a description of management's approach to determining the } \\
\text { value(s) assigned to each key assumption, whether those } \\
\text { value(s) reflect past experience or, if appropriate, are } \\
\text { consistent with external sources of information, and, if not, } \\
\text { how and why they differ from past experience or external } \\
\text { sources of information. }\end{array}$ & $0-1$ \\
\hline IAS36-p134-d-iii & $\begin{array}{l}\text { the period over which management has projected cash flows } \\
\text { based on financial budgets/forecasts approved by } \\
\text { management and, when a period greater than five years is } \\
\text { used for a cash-generating unit (group of units), an } \\
\text { explanation of why that longer period is justified. }\end{array}$ & $0-1$ \\
\hline IAS36-p134-d-iv & $\begin{array}{l}\text { the growth rate used to extrapolate cash flow projections } \\
\text { beyond } \\
\text { the period covered by the most recent budgets/forecasts, and } \\
\text { the justification for using any growth rate that exceeds the } \\
\text { long-term } \\
\text { average growth rate for the products, industries, or country or } \\
\text { countries in which the entity operates, or for the market to } \\
\text { which the unit (group of units) is dedicated. }\end{array}$ & $0-1$ \\
\hline IAS36-p134-d-v & the discount rate(s) applied to the cash flow projections. & $0-1$ \\
\hline
\end{tabular}




\section{Appendix B - Additional tests for the validity of the disclosure scores}

We validate our measure of goodwill related mandatory disclosure by testing its association with variables identified in prior relevant literature (i.e., Wallace et al. 1994, Ali et al. 2004, Glaum et al. 2013, Tsalavoutas et al. 2014) as significant determinants of mandatory disclosure levels. We do so in five multivariate regression models where the three disclosure measures we employ in the main analysis (namely DiscSaidin, DiscScaled and DiscRaw) as well as the actual score (Disc) and the transformed score we use in the sensitivity analysis (DRank in line with Botosan 1997) are the dependent variables. The independent variables used are as follows. $G d w B V$ (the \% of goodwill to book value of equity), MaterialIL (a dummy variable that equals one if the firm has experienced a material impairment loss on goodwill (more than $5 \%$ of goodwill at beginning of year $t$ as reported in the financial statements) and 0 otherwise), MaterialBC (a dummy variable that takes one in case a firm experienced a material business combination (more than $5 \%$ of total assets or sales) and 0 otherwise, as at beginning of the year as reported in the financial statements), MrktMet (a dummy variable that equals one if a firm met the market expectation in terms of goodwill impairment loss and zero otherwise). Size (natural logarithm of market value), Leverage (total debt to book value of equity), Liquidity (current assets to current liabilities), ROA (return on assets), Strategic Ownership (aggregate \% of ownership held by institutional investors and pension funds who hold more than 5\% of companies' shares), Enforcement (the Brown et al. (2014) index relating to the enforcement body i.e., its powers, activities and resources across countries) and dummy variables capturing industry participation.

Table B1 documents descriptive statistics for the dependent and independent variables not used in the paper's main analysis but used only for validating our disclosure scores. Table B2 presents the findings of this validation process. Results show that our disclosure measures are consistently positively and statistically significantly associated with size (Size) and with \% of goodwill to book value of equity $(G d w B V)$. Recognising a material impairment loss (MaterialIL) and meeting the market expectation in terms of goodwill impairment loss (MrktMet) also increase disclosure. Additionally, all five disclosure scores are consistently negatively associated with the occurrence and reporting of a material business combination (MaterialBC). Moreover, we find that the three non-country adjusted scores (Disc, DRank and DiscSaidin) are positively associated with Enforcement while the two country adjusted scores (DiscScaled and DiscRaw) are positively associated with Strategic Ownership instead. These results confirm validity of our disclosure measures as they are consistent with our expectations and prior literature. Moreover, the fact that the two country adjusted scores are not statistically significantly associated with enforcement allows us to also conclude that these two disclosure scores are not alternative proxies for enforcement.

Table B1 - Descriptive statistics for dependent and independent variables not reported in the paper but in the index validation models

\begin{tabular}{lcccccc}
\hline \multicolumn{1}{c}{ Variable } & $\boldsymbol{n}$ & Mean & St. dev & Min & Median & Max \\
\hline Disc & 831 & 0.823 & 0.137 & 0.333 & 0.833 & 1.000 \\
DRank & 831 & 0.610 & 0.291 & 0.000 & 0.597 & 1.000 \\
MaterialIL & 831 & 0.087 & 0.281 & 0 & 0 & 1 \\
MaterialBC & 831 & 0.723 & 0.448 & 0 & 1 & 1 \\
MrktMet & 831 & 0.702 & 0.458 & 0 & 1 & 1 \\
Strategic Ownership & 831 & 0.062 & 0.082 & 0.000 & 0.050 & 0.460 \\
Liquidity & 831 & 1.265 & 0.547 & 0.279 & 1.134 & 3.877 \\
\hline
\end{tabular}


Table B2 - Multivariate Tests for Index validation

\begin{tabular}{|c|c|c|c|c|c|}
\hline VARIABLES & Disc & DRank & DiscSaidin & DiscScaled & DiscRaw \\
\hline Constant & $\begin{array}{c}0.719 * * * \\
(14.93)\end{array}$ & $\begin{array}{c}0.381 * * * \\
(3.70)\end{array}$ & $\begin{array}{c}0.488^{* * *} \\
(6.64)\end{array}$ & $\begin{array}{c}0.129 \\
(0.90)\end{array}$ & $\begin{array}{c}0.130 * * \\
(2.46)\end{array}$ \\
\hline$G d w B V^{\mathrm{a}}$ & $\begin{array}{c}0.035 * * * \\
(2.98)\end{array}$ & $\begin{array}{c}0.084 * * * \\
(3.27)\end{array}$ & $\begin{array}{c}0.039 * * \\
(1.99)\end{array}$ & $\begin{array}{c}0.120 * * * \\
(2.78)\end{array}$ & $\begin{array}{c}0.058 * * * \\
(3.91)\end{array}$ \\
\hline MaterialIL & $\begin{array}{c}0.097 * * * \\
(6.53)\end{array}$ & $\begin{array}{c}0.229 * * * \\
(6.89)\end{array}$ & $\begin{array}{c}0.168 * * * \\
(6.86)\end{array}$ & $\begin{array}{c}0.263 * * * \\
(5.15)\end{array}$ & $\begin{array}{c}0.109 * * * \\
(6.40)\end{array}$ \\
\hline MaterialBC & $\begin{array}{c}-0.057 * * * \\
(-4.58)\end{array}$ & $\begin{array}{c}-0.127 * * * \\
(-4.90)\end{array}$ & $\begin{array}{c}-0.254 * * * \\
(-12.40)\end{array}$ & $\begin{array}{c}-0.067 * \\
(-1.69)\end{array}$ & $\begin{array}{c}-0.048 * * * \\
(-3.54)\end{array}$ \\
\hline MrktMet & $\begin{array}{c}0.045^{* * *} \\
(3.85)\end{array}$ & $\begin{array}{c}0.101 * * * \\
(3.82)\end{array}$ & $\begin{array}{l}0.029 \\
(1.40)\end{array}$ & $\begin{array}{c}0.117 * * * \\
(3.50)\end{array}$ & $\begin{array}{c}0.048 * * * \\
(3.82)\end{array}$ \\
\hline Size & $\begin{array}{c}0.007 * * \\
(2.08)\end{array}$ & $\begin{array}{c}0.016^{* *} \\
(2.13)\end{array}$ & $\begin{array}{l}0.007^{*} \\
(1.93)\end{array}$ & $\begin{array}{c}0.014 * * * \\
(2.83)\end{array}$ & $\begin{array}{c}0.013 * * * \\
(2.72)\end{array}$ \\
\hline Leverage $^{\text {a }}$ & $\begin{array}{l}-0.004 \\
(-0.55)\end{array}$ & $\begin{array}{l}-0.005 \\
(-0.32)\end{array}$ & $\begin{array}{l}-0.001 \\
(-0.08)\end{array}$ & $\begin{array}{l}-0.026 \\
(-1.28)\end{array}$ & $\begin{array}{l}-0.011 \\
(-1.41)\end{array}$ \\
\hline$R O A^{\mathrm{a}}$ & $\begin{array}{l}0.127 \\
(0.85)\end{array}$ & $\begin{array}{l}0.239 \\
(0.78)\end{array}$ & $\begin{array}{l}0.320 \\
(1.42)\end{array}$ & $\begin{array}{c}0.081 \\
(0.17)\end{array}$ & $\begin{array}{l}0.001 \\
(0.01)\end{array}$ \\
\hline Strategic Ownership ${ }^{\text {a }}$ & $\begin{array}{l}-0.008 \\
(-0.11)\end{array}$ & $\begin{array}{l}-0.039 \\
(-0.23)\end{array}$ & $\begin{array}{l}-0.031 \\
(-0.25)\end{array}$ & $\begin{array}{c}0.792 * * * \\
(3.60)\end{array}$ & $\begin{array}{c}0.208 * * \\
(2.54)\end{array}$ \\
\hline Liquidity & $\begin{array}{c}0.008 \\
(0.49)\end{array}$ & $\begin{array}{l}0.017 \\
(0.52)\end{array}$ & $\begin{array}{l}0.015 \\
(0.59)\end{array}$ & $\begin{array}{l}-0.047 \\
(-0.91)\end{array}$ & $\begin{array}{l}-0.007 \\
(-0.41)\end{array}$ \\
\hline Enforcement & $\begin{array}{c}0.003 * * \\
(2.15)\end{array}$ & $\begin{array}{c}0.009^{* *} \\
(2.52)\end{array}$ & $\begin{array}{c}0.008 * * * \\
(3.26)\end{array}$ & $\begin{array}{c}0.023 \\
(1.03)\end{array}$ & $\begin{array}{l}0.006 \\
(1.26)\end{array}$ \\
\hline Industry dummies & Included & Included & Included & Included & Included \\
\hline Year dummies & Included & Included & Included & Included & Included \\
\hline$N$ & 831 & 831 & 831 & 831 & 831 \\
\hline$F$ & $8.65 * * *$ & $9.48 * * *$ & $18.41^{* * *}$ & $18.89 * * *$ & $16.65 * * *$ \\
\hline$R^{2}-a d j$ & 0.136 & 0.167 & 0.270 & 0.330 & 0.277 \\
\hline Mean VIF & 1.65 & 1.65 & 1.65 & 1.65 & 1.65 \\
\hline
\end{tabular}

a Variables winsorised at the 2 nd and 98 th percentiles. $*$, **, *** denote significance at the $10 \%, 5 \%$ and $1 \%$ level respectively. 


\section{Appendix C - Description of Implied cost of equity (ICC) models used}

\section{Claus and Thomas (2001) - Economy-wide model (CT)}

Claus and Thomas (2001) list a number of concerns about the dividend discount model, proposing a new measure of implied cost of equity based on a residual income valuation model.

$$
P_{0}=\text { bvps }_{0}+\sum_{t=1}^{5} \frac{A E_{t}}{\left(1+r_{C T}\right)^{t}}+\frac{A E_{5}\left(1+g_{a e}\right)}{\left(r_{C T}-g_{a e}\right)\left(1+r_{C T}\right)^{5}}
$$

where $A E_{t}$ represents abnormal earnings in year $t$ and are calculated as $A E_{t}=E P S_{t}-r_{C T}\left(b v p s_{t-1}\right), E P S$ are earnings per share, bvps is the book value per share, $P_{0}$ is current price, and $g_{a e}$ a long-term growth beyond period five, which is set equal to the forecasted inflation.

\section{Gebhardt et al. (2001) - Industry model (GLS)}

Gebhardt et al. (2001) model is similar to the Claus and Thomas (2001) economy-wide model, particularly in that both are residual income models. However, $r_{G L S}$ differs from $r_{C T}$ in two basic assumptions. First, the forecast period is based on 11 years, where the first 3 years use specific forecasts. For the remaining period it is assumed that firm return on equity ( $R O E$ ) will gradually fade to a target $R O E$. Secondly, $r_{G L S}$ assumes zero growth in its terminal value.

$$
P_{0}=b v p s_{0}+\sum_{t=1}^{11} \frac{\left(R O E_{t}-r_{G L S}\right) b v p s_{t-1}}{\left(1+r_{G L S}\right)^{t}}+\frac{\left(R O E_{12}-r_{G L S}\right) b v p s_{11}}{\left(1+r_{G L S}\right)^{12}}
$$

\section{Gode and Mohanram (2003) - Modified economy-wide growth model (GM)}

This measure is an implementation of the economy-wide growth model by Ohlson and Juettner-Nauroth (2005).

$$
r_{G M}=A+\sqrt{A^{2}+\frac{E P S_{1}}{P_{0}}\left(g_{s t}-g_{a e}\right)}
$$

where $A=\frac{g_{a e}+\frac{D P S_{1}}{P_{0}}}{2}, D P S$ is dividend per share and $g_{s t}$ is a short-term growth. $r_{G M}$ considers that short term growth can be set equal to $g_{s t}=\frac{E P S_{2}-E P S_{1}}{2}$.

\section{Easton (2004) - Modified price-earnings growth (PEG) models}

Easton (2004) builds on Ohlson and Juettner-Nauroth (2005), assuming that market expects no growth in abnormal earnings used in the terminal value.

$$
r_{M P E G}=A+\sqrt{A^{2}+\left(\frac{E P S_{2}-E P S_{1}}{P_{0}}\right)}
$$

where $A=\frac{D P S_{1}}{2 P_{0}}$. Among the various measured proposed by Easton (2004), we employ $r_{M P E G}$, since it allows for dividend paid at $t=1$, while the other models assume no dividends.

\section{Further assumptions}

To estimate ICC we require each observation to have at least 1- and 2-year ahead EPS forecasts and price $(P)$. We use analysts EPS forecasts, DPS forecasts, and long-term growth $(L T G)$ forecasts from $\mathrm{I} / \mathrm{B} / \mathrm{E} / \mathrm{S}$, and stock prices $(P)$ from Datastream. Many studies measure forecasted EPS, DPS, $L T G$ and $P$ in a range from +4 to +10 months from financial year end $t$ (e.g., Botosan and Plumlee 2005, Hail and Leuz 2006). To ensure regulatory filings are publicly available and reasonably priced (Frankel and Lee 1999), we consider mean analysts forecasts and prices as of month +5 . Following Hail and Leuz (2006), we do not discount earnings or dividend forecasts, however we use $(1+I C C)^{-5 / 12}$ as a discount factor for $P$. bvps for $t=0$ is the ratio of equity book value to number of shares outstanding. For expected bvps from $t=1$ to $t=11$, we impose $b v p s_{t}=b v p s_{t-1}+E P S_{t}-$ $D P S_{t}$ (c.f., Dhaliwal et al. 2007). In case of data unavailability, we use the following criteria. Unavailable EPS forecasts for $t=3$ to $t=5$ are estimated as $E P S_{t+1}=(1+L T G)$, when $E P S_{t}>0$ (Claus and Thomas 2001, Dhaliwal et al. 2007). If $E P S_{t} \leq 0$, we use $E P S_{t+k}=E P S_{t}(1+L T G)^{k}$. To calculate a missing $D P S_{t}$ we use the firm's dividend-pay-out ratio $(D P R)$. We calculate forecasted $D P S_{t}$ as $D P S_{t}=E P S_{t} \times D P R_{0}$ (Gode and Mohanram 2003, Dhaliwal et al. 2007). $D P R_{0}$ is computed as the ratio of DPS to EPS, based on the average of three years preceding financial year end $t$. When $D P R$ is missing or not falling in the range from 0 to 1 , we replace it with the country-year median DPR (Hail and Leuz 2006). When LTG is not available, we estimate it as $\left(E P S_{2} / E P S_{1}\right)-1$ (Gode and Mohanram 2003). 
Table 1 - Sample selection

Panel A Sample selection process

The sample selection process considers as a starting point all the S\&P EU350 constituents from $31^{\text {st }}$ December 2008 to $31^{\text {st }}$ December 2011

\begin{tabular}{|c|c|c|c|c|c|c|c|c|c|c|}
\hline \multicolumn{2}{|c|}{1,400} & \multicolumn{9}{|c|}{ starting observations [350 firms for 4 years $(2008 ; 2009 ; 2010$; and 2011$)]$} \\
\hline \multicolumn{2}{|c|}{$\begin{array}{l}n \text { observations } \\
\text { excluded thereafter }\end{array}$} & \multicolumn{9}{|c|}{ Reason for exclusion } \\
\hline 29 & & \multicolumn{9}{|c|}{ classified as Financials (c.f., Hail 2002, Nikolaev and van Lent 2005) } \\
\hline 20 & & \multicolumn{9}{|c|}{ present twice in the S\&P EU350 constituents ${ }^{\text {a }}$} \\
\hline 19 & & \multicolumn{9}{|c|}{ reporting under U.S. GAAP } \\
\hline 4 & & \multirow{2}{*}{\multicolumn{9}{|c|}{$\begin{array}{l}\text { annual report not publicly available because the firms delisted before issuing it } \\
\text { changed annual report ending period }\end{array}$}} \\
\hline 3 & & & & & & & & & & \\
\hline 8 & & \multicolumn{9}{|c|}{ missing country controls for Luxembourg } \\
\hline 41 & & \multicolumn{9}{|c|}{ negative book value of equity } \\
\hline 18 & & \multicolumn{9}{|c|}{ goodwill to book value of equity below $5 \%$} \\
\hline \multicolumn{2}{|c|}{831} & \multicolumn{9}{|c|}{ final sample } \\
\hline \multicolumn{11}{|c|}{ Panel B - Sample constituents by Country and Industry } \\
\hline \multicolumn{11}{|c|}{ ICB industry classification ${ }^{\mathrm{b}}$} \\
\hline Country & $\begin{array}{c}\text { Basic } \\
\text { mat. }\end{array}$ & $\begin{array}{l}\text { Cons. } \\
\text { goods }\end{array}$ & $\begin{array}{c}\text { Cons. } \\
\text { services }\end{array}$ & $\begin{array}{c}\text { Health } \\
\text { care }\end{array}$ & $\begin{array}{c}\text { Indus- } \\
\text { trials }\end{array}$ & $\begin{array}{c}\text { Oil and } \\
\text { gas }\end{array}$ & $\begin{array}{l}\text { Tech- } \\
\text { nology }\end{array}$ & Telec. & Utilities & TOT \\
\hline Austria & 5 & 0 & 0 & 0 & 0 & 2 & 0 & 4 & 0 & 11 \\
\hline Belgium & 6 & 4 & 6 & 4 & 1 & 0 & 0 & 4 & 0 & 25 \\
\hline Denmark & 0 & 4 & 0 & 4 & 0 & 4 & 0 & 0 & 0 & 12 \\
\hline Finland & 4 & 0 & 0 & 0 & 11 & 0 & 4 & 0 & 0 & 19 \\
\hline France & 4 & 32 & 39 & 8 & 39 & 4 & 15 & 4 & 16 & 161 \\
\hline Germany & 16 & 20 & 11 & 8 & 20 & 0 & 6 & 4 & 8 & 93 \\
\hline Greece & 0 & 0 & 0 & 0 & 0 & 0 & 0 & 4 & 0 & 4 \\
\hline Ireland & 0 & 3 & 0 & 1 & 0 & 0 & 0 & 0 & 0 & 4 \\
\hline Italy & 0 & 10 & 5 & 0 & 8 & 8 & 0 & 4 & 7 & 42 \\
\hline Netherland & 10 & 9 & 7 & 3 & 6 & 0 & 3 & 4 & 0 & 42 \\
\hline Norway & 5 & 4 & 0 & 0 & 0 & 2 & 0 & 4 & 0 & 15 \\
\hline Portugal & 0 & 0 & 0 & 0 & 4 & 2 & 0 & 4 & 4 & 14 \\
\hline Spain & 0 & 0 & 1 & 0 & 16 & 8 & 0 & 4 & 7 & 36 \\
\hline Sweden & 8 & 10 & 0 & 0 & 35 & 0 & 4 & 8 & 0 & 65 \\
\hline Switzerland & 12 & 6 & 0 & 14 & 6 & 0 & 0 & 4 & 0 & 42 \\
\hline UK & 17 & 40 & 68 & 12 & 57 & 7 & 16 & 10 & 19 & 246 \\
\hline TOT & 87 & 142 & 137 & 54 & 203 & 37 & 48 & 62 & 61 & 831 \\
\hline
\end{tabular}

a To avoid double counting, firms that are cross-listed in more than one European market are included in our sample once, based only on the country of primary listing.

${ }^{\mathrm{b}}$ Based on the Industry Classification Benchmark (ICB) Level 2. 
Table 2 - Descriptive statistics for mandatory disclosure levels

\begin{tabular}{|c|c|c|c|c|c|c|c|c|c|c|}
\hline \multicolumn{11}{|c|}{ Panel A - Descriptive statistics by year } \\
\hline Statistics & \multicolumn{2}{|c|}{2008} & \multicolumn{2}{|c|}{2009} & \multicolumn{2}{|c|}{2010} & \multicolumn{2}{|c|}{2011} & \multicolumn{2}{|c|}{ 2008-2011 } \\
\hline Mean & \multicolumn{2}{|c|}{0.778} & \multicolumn{2}{|c|}{0.819} & \multicolumn{2}{|c|}{0.857} & \multicolumn{2}{|c|}{0.840} & \multicolumn{2}{|c|}{0.823} \\
\hline St. dev. & \multicolumn{2}{|c|}{0.117} & \multicolumn{2}{|c|}{0.117} & \multicolumn{2}{|c|}{0.173} & \multicolumn{2}{|c|}{0.117} & \multicolumn{2}{|c|}{0.137} \\
\hline Min & \multicolumn{2}{|c|}{0.333} & \multicolumn{2}{|c|}{0.500} & \multicolumn{2}{|c|}{0.333} & \multicolumn{2}{|c|}{0.500} & \multicolumn{2}{|c|}{0.333} \\
\hline Median & \multicolumn{2}{|c|}{0.786} & \multicolumn{2}{|c|}{0.824} & & & & & & \\
\hline Max & & & & & & 00 & & & & \\
\hline$N$ & & & & & & & & & & \\
\hline & & & & el B - & for 1 & nd & & & & \\
\hline & & & & zick tes & 6.28 & & & & & \\
\hline FOLLOW & EST & & $8-20$ & & & 009-201 & & & 2010-20 & \\
\hline Mann-W & & & $583 *$ & & & $4.592 * *$ & & & $3.215^{* *}$ & \\
\hline$T$-te & & & $613 *$ & & & $2.617 * *$ & & & 1.115 & \\
\hline & & Panel C & Frequ & cy by l & lof $\mathrm{c}$ & npliance & d yea & & & \\
\hline Level & & & & & & & & & 200 & 2011 \\
\hline$\%$ & $n$ & $\%$ & $n$ & $\%$ & $n$ & $\%$ & $n$ & $\%$ & $n$ & $\%$ \\
\hline $31-40$ & 1 & 0.5 & 0 & 0.0 & 6 & 2.8 & 0 & 0.0 & 7 & 0.8 \\
\hline $41-50$ & 3 & 1.5 & 3 & 1.4 & 7 & 3.3 & 1 & 0.5 & 14 & 1.7 \\
\hline $51-60$ & 10 & 4.8 & 10 & 4.7 & 9 & 4.2 & 5 & 2.5 & 34 & 4.1 \\
\hline $61-70$ & 37 & 17.9 & 22 & 10.3 & 12 & 5.6 & 20 & 10.2 & 91 & 11.0 \\
\hline $71-80$ & 59 & 28.5 & 46 & 21.5 & 31 & 14.6 & 35 & 17.8 & 171 & 20.6 \\
\hline $81-90$ & 68 & 32.9 & 74 & 34.6 & 45 & 21.1 & 66 & 33.5 & 253 & 30.5 \\
\hline $91-100$ & 29 & 14.0 & 59 & 27.6 & 103 & 48.4 & 70 & 35.5 & 261 & 31.4 \\
\hline$N$ & 207 & 100.0 & 214 & 100.0 & 213 & 100.0 & 197 & 100.0 & 831 & 100.0 \\
\hline & & Pan & $-\mathbf{M}$ & n (med & by c & intry an & ear & & & \\
\hline Country & & & & & & & & & 200 & 2011 \\
\hline Austria & 0.74 & $0.746)$ & 0.85 & $0.854)$ & 0.86 & $(0.875)$ & 0.736 & $0.736)$ & $0.80^{\prime}$ & $0.850)$ \\
\hline Belgium & 0.74 & $0.750)$ & 0.73 & $0.750)$ & 0.67 & $(0.774)$ & 0.738 & $0.746)$ & 0.72 & $0.750)$ \\
\hline Denmark & 0.83 & $0.875)$ & $0.91^{\prime}$ & 0.933) & 0.92 & $1.000)$ & 0.952 & $1.000)$ & 0.90 & $0.967)$ \\
\hline Finland & $0.77^{\prime}$ & $0.774)$ & 0.85 & $0.875)$ & 0.88 & $(0.857)$ & 0.941 & $1.000)$ & 0.87 & $0.867)$ \\
\hline France & 0.73 & $0.731)$ & 0.75 & $0.765)$ & 0.77 & $(0.778)$ & 0.755 & $0.750)$ & 0.75 & $0.760)$ \\
\hline Germany & 0.76 & $0.765)$ & 0.83 & $0.861)$ & 0.92 & $(1.000)$ & 0.886 & 0.909) & 0.85 & $0.875)$ \\
\hline Greece & $0.72^{\prime}$ & $0.727)$ & 0.76 & $0.769)$ & 1.00 & $(1.000)$ & 0.579 & $0.579)$ & 0.76 & $0.748)$ \\
\hline Ireland & 0.85 & $0.857)$ & 0.95 & $0.952)$ & 1.00 & $1.000)$ & 0.950 & $0.950)$ & 0.940 & $0.951)$ \\
\hline Italy & 0.78 & $0.782)$ & 0.82 & $0.810)$ & 0.84 & $(0.857)$ & 0.872 & $0.882)$ & 0.83 & $0.823)$ \\
\hline Netherlands & 0.80 & $0.805)$ & 0.79 & $0.800)$ & 0.87 & $(0.882)$ & 0.863 & 0.909) & 0.83 & $0.875)$ \\
\hline Norway & 0.80 & $0.811)$ & 0.77 & $0.800)$ & 0.90 & $(1.000)$ & 0.827 & $0.824)$ & 0.82 & $0.815)$ \\
\hline Portugal & 0.71 & $0.706)$ & 0.71 & 0.769) & 0.69 & $(0.746)$ & 0.765 & $0.794)$ & 0.72 & $0.767)$ \\
\hline Spain & 0.67 & $0.671)$ & 0.74 & $0.768)$ & 0.71 & $(0.675)$ & 0.797 & $0.789)$ & 0.73 & $0.743)$ \\
\hline Sweden & $0.78^{\prime}$ & $0.782)$ & 0.82 & $0.824)$ & 0.92 & $(1.000)$ & 0.880 & $0.868)$ & 0.84 & $0.857)$ \\
\hline Switzerland & 0.82 & $0.824)$ & 0.87 & 0.894) & 0.90 & $(0.969)$ & 0.884 & $0.900)$ & 0.87 & $0.889)$ \\
\hline UK & 0.81 & $0.842)$ & 0.86 & $0.889)$ & 0.89 & $(1.000)$ & 0.869 & $0.889)$ & 0.85 & $0.882)$ \\
\hline
\end{tabular}

Disclosure level is calculated as the ratio of the total items disclosed by a company to the maximum number of applicable items for that company (and with which compliance is expected). Disclosure lies between 0 and 1 (see Eq.(1)).

${ }^{a}$ Cuzick test is a non-parametric test for trend across ordered groups (see Cuzick 1985). Mann-Whitney and Ttest examine the median and mean differences between two periods respectively. $*, * *, * * *$ denote significance at the $10 \%, 5 \%$ and $1 \%$ level respectively. 
Table 3 - Paragraphs in IFRS 3 and IAS 36 for which high non-compliance is observed ${ }^{\text {a }}$

Panel A - IFRS 3 Business combinations

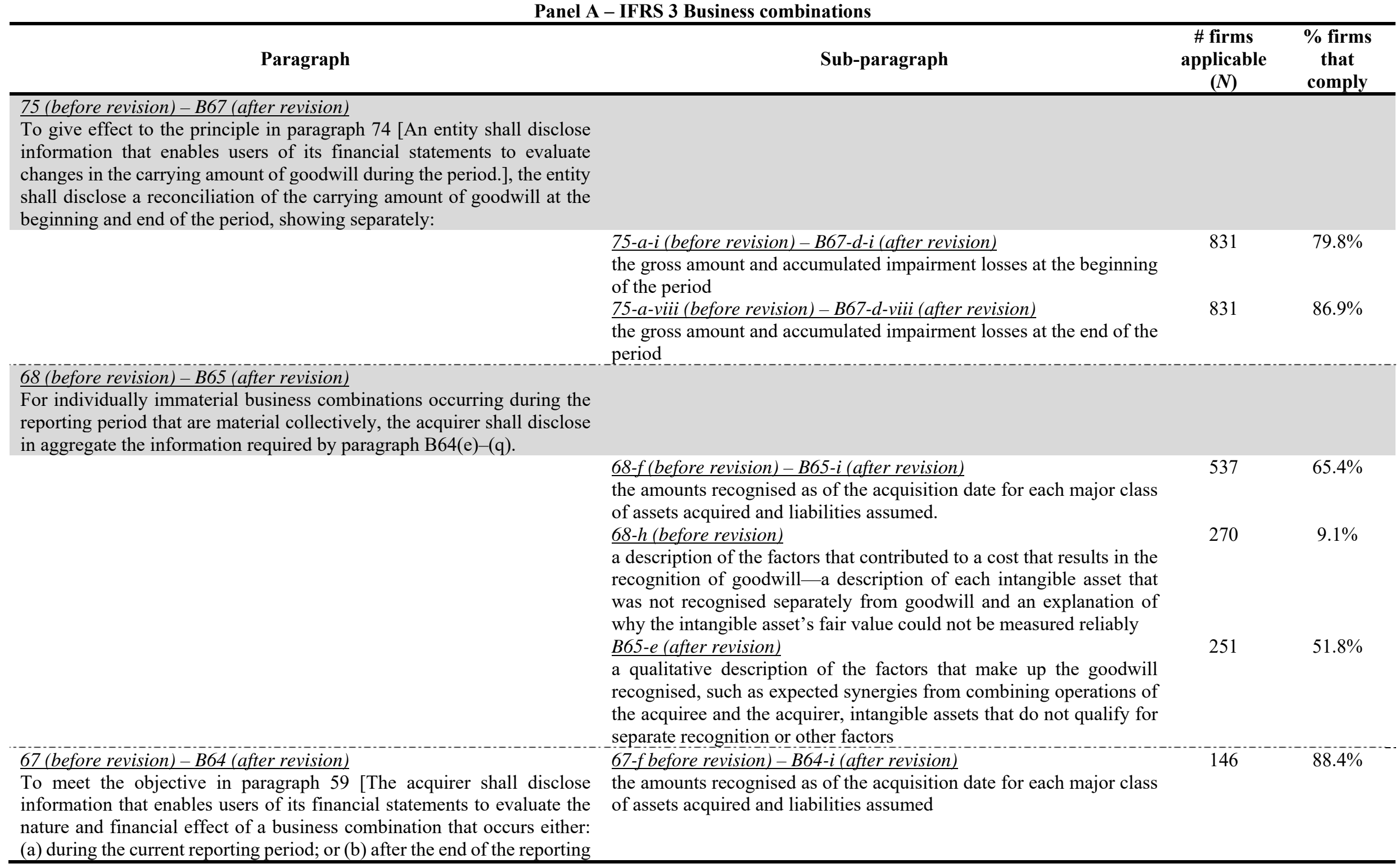


period but before the financial statements are authorised for issue], the acquirer shall disclose the following information for each business combination that occurs during the reporting period:

\section{Panel B - IAS 36 Impairment of Assets}

\# firms

applicable

(N)

$\%$ firms

Paragraph

\section{$\underline{134}$}

An entity shall disclose the information required by (a)-(f) for each cashgenerating unit (group of units) for which the carrying amount of goodwill or intangible assets with indefinite useful lives allocated to that uni (group of units) is significant in comparison with the entity's total carrying amount of goodwill or intangible assets with indefinite useful lives

\section{Sub-paragraph}

$\underline{134-d}$

if the unit's (group of units') recoverable amount is based on value in use $\underline{134-d-i i}$

a description of management's approach to determining the value(s) assigned to each key assumption, whether those value(s) reflect past experience or, if appropriate, are consistent with external sources of information, and, if not, how and why they differ from past experience or external sources of information

$\underline{134-d-i}$

a description of each key assumption on which management has based its cash flow projections for the period covered by the most recent budgets/forecasts. Key assumptions are those to which the unit's (group of units') recoverable amount is most sensitive

\section{4-d-iii}

the period over which management has projected cash flows based on financial budgets/forecasts approved by management and, when a period greater than five years is used for a cash-generating unit (group of units), an explanation of why that longer period is justified

$\underline{129-a}$

the amount of impairment losses recognised in profit or loss and in

An entity that reports segment information in accordance with IFRS 8 shall disclose the following for each reportable segment

131

An entity shall disclose the following information for the aggregate impairment losses recognised during the period for which no information is disclosed in accordance with paragraph 130

$\underline{134}$

An entity shall disclose the information required by (a)-(f) for each cashgenerating unit (group of units) for which the carrying amount of goodwill other comprehensive income during the period

$\underline{131-b}$

the main events and circumstances that led to the recognition of these impairment losses

$134-e$

if the unit's (group of units') recoverable amount is based on fair value less costs to sell, the methodology used to determine fair value less 


134
An entity shall disclose the information required by (a)-(f) for each cash-
generating unit (group of units) for which the carrying amount of goodwill
or intangible assets with indefinite useful lives allocated to that unit
(group of units) is significant in comparison with the entity's total
carrying amount of goodwill or intangible assets with indefinite useful
lives

a description of management's approach to determining the value (or values) assigned to each key assumption, whether those values reflect past experience or, if appropriate, are consistent with external sources of information, and, if not, how and why they differ from past experience or external sources of information

134-e-i

a description of each key assumption on which management has based its determination of fair value less costs to sell. Key assumptions are those to which the unit's (group of units') recoverable amount is most sensitive

\section{$\underline{134-f}$}

if a reasonably possible change in a key assumption on which management has based its determination of the unit's (group of units') recoverable amount would cause the unit's (group of units') carrying amount to exceed its recoverable amount

\section{4-f-iii}

the amount by which the value assigned to the key assumption must change, after incorporating any consequential effects of that change on the other variables used to measure recoverable amount, in order for the unit's (group of units') recoverable amount to be equal to its carrying amount

\section{$\underline{134-f-i}$}

the amount by which the unit's (group of units') recoverable amount exceeds its carrying amount

the value assigned to the key assumption 
${ }^{a}$ In case some disclosure items were required in different paragraphs after the revision of IFRS3, we report the paragraph number both before revision and after revision. In such cases, we report the version under the revised version of the standard. 
Table 4 - Descriptive statistics for dependent and independent variables

\begin{tabular}{|c|c|c|c|c|c|c|}
\hline \multicolumn{7}{|c|}{ Panel A - Firm and Country specific control variables } \\
\hline Variable & $n$ & Mean & St. dev & Min & Median & Max \\
\hline DiscSaidin & 831 & 0.564 & 0.253 & 0.013 & 0.555 & 1.000 \\
\hline DiscScaled & 831 & 0.614 & 0.556 & 0.000 & 0.467 & 2.000 \\
\hline DiscRaw & 831 & 0.275 & 0.179 & 0.000 & 0.257 & 0.667 \\
\hline$G d w B V$ & 831 & 0.699 & 0.894 & 0.050 & 0.507 & 16.900 \\
\hline PageCount & 831 & 200 & 89 & 54 & 179 & 620 \\
\hline$A W C A$ & 831 & 0.026 & 0.032 & 0.000 & 0.017 & 0.289 \\
\hline$R O A$ & 831 & 0.048 & 0.061 & -0.786 & 0.044 & 0.356 \\
\hline$M 2 B$ & 831 & 2.673 & 3.365 & 0.191 & 1.935 & 43.806 \\
\hline Leverage & 831 & 1.153 & 1.657 & 0.000 & 0.710 & 28.419 \\
\hline$M V$ & 831 & 15,639 & 21,365 & 240 & 7,279 & 148,083 \\
\hline$r V a r$ & 831 & 0.011 & 0.015 & 0.000 & 0.007 & 0.199 \\
\hline Dispersion & 831 & 0.999 & 2.222 & 0.000 & 0.290 & 27.370 \\
\hline MrktDev & 831 & 0.769 & 0.458 & 0.113 & 0.692 & 2.322 \\
\hline Enforcement & 831 & 18 & 4 & 8 & 21 & 22 \\
\hline \multicolumn{7}{|c|}{ Panel B - Dependent variable implied cost of equity $r_{A V}$} \\
\hline Statistics & & & 2009 & 2010 & 2011 & 2008-2011 \\
\hline Mean & & & 0.109 & 0.105 & 0.118 & 0.111 \\
\hline St. dev. & & & 0.038 & 0.032 & 0.048 & 0.040 \\
\hline Min & & & 0.010 & 0.017 & 0.017 & 0.010 \\
\hline Median & & & 0.107 & 0.104 & 0.109 & 0.106 \\
\hline Max & & & 0.324 & 0.253 & 0.302 & 0.324 \\
\hline$N$ & & & 214 & 213 & 197 & 831 \\
\hline \multicolumn{7}{|c|}{ Panel $\mathrm{C}$ - Test for trend in implied cost of equity $\boldsymbol{r}_{A V}$} \\
\hline \multicolumn{7}{|c|}{ Cuzick test ${ }^{\mathrm{a}} \quad 0.930$} \\
\hline Follow-up Tests & & & 2009 & 2009 & & 2010-2011 \\
\hline Mann-Whitney ${ }^{\mathrm{a}}$ & & & & 0.9 & & $-2.267 * *$ \\
\hline T-test ${ }^{\mathrm{a}}$ & & & 66 & 1.1 & & $-3.359 * * *$ \\
\hline \multicolumn{7}{|c|}{ Panel D - Pearson's correlation coefficients for implied cost of equity } \\
\hline$r_{C T}$ & & & $r_{G L S}$ & $r_{G M}$ & $r_{M P E G}$ & $r_{A V}$ \\
\hline$r_{G L S}$ & & k** & 1 & & & \\
\hline$r_{G M}$ & & k** & $0.369 * * *$ & 1 & & \\
\hline$r_{M P E G}$ & & *** & $0.544 * * *$ & $0.547 * * *$ & 1 & \\
\hline$r_{A V}$ & & k** & $0.818 * * *$ & $0.753 * * *$ & $0.871 * * *$ & 1 \\
\hline
\end{tabular}

Panel A reports descriptive statistics for the independent variables. DiscSaidin is a disclosure score which weights each disclosure item by the percentage of firms in the sample that do not comply with the item (Hodgdon et al., 2008). DiscScaled and DiscRaw are transformations of actual mandatory disclosure levels (Francis et al., 2005). DiscRaw is the difference between a firm's disclosure and the country-minimum score the firm is incorporated in. DiscScaled is DiscRaw scaled by the country-minimum score. GdwBV is goodwill (GDW from Compustat) to book value of equity (WC03501). PageCount is the number of pages of each annual report. This is used for computing the Readability measure employed in the subsequent analyses $(\ln$ (PageCount)). AWCA is the absolute value of abnormal working capital accruals scaled by the end-of-the-year total assets (DeFond and Park 2001). AWCA = $\left(W C_{t}-W C_{t-1} * S_{t} / S_{t-1}\right) / T A_{t}$. WC stands for working capital accruals, computed as current assets (WC02201) - cash $\&$ equivalents (WC02001) - current liabilities (WC03101) + short term debt (WC03051). $S$ and TA stand for sales and total assets (WC02999), respectively. ROA is return on assets calculated as the ratio between net income and total assets (WC01751 / WC02999). M2B is the market value to book value of equity. Leverage is the ratio between total debt and book value of equity (WC03255/WC03501). $M V$ is market value ( $€$ millions; WC08001). $M V$ is used for computing the Size variable employed in the subsequent analyses $(\ln (M V))$. $r$ Var is the return variance over the financial year. All accounting and market data refer to year $t=0$. Dispersion is the standard deviation of the last forecast before earnings announcement. MrktDev is the market capitalisation of listed companies as a \% of GDP. Enforcement is an index capturing the strength of the enforcement body in each country (Brown et al., 2014). Panel $\mathrm{B}$ reports descriptive statistics for the implied cost of equity proxy (ICC) used, $r_{A V}$, which is a simple average measure of the $r_{C T}$ (Claus and Thomas 2001), $r_{G L S}$ (Gebhardt et al. 2001), $r_{G M}$ (Gode and Mohanran 2003), $r_{M P E G}$ (Easton 2004). Further information about the ICC models can be found in Appendices B and C. Panel C tests for trend in ICC and Panel D presents Pearson correlations among the ICC calculated.

${ }^{a}$ Cuzick test is a non-parametric test for trend across ordered groups (see Cuzick 1985). Mann-Whitney and T-test examine the median and mean differences between two periods respectively. 
$*, * *, * * *$ denote significance at the $10 \%, 5 \%$ and $1 \%$ level respectively. 
Table 5 - Pearson's correlation coefficients

\begin{tabular}{|c|c|c|c|c|c|c|c|c|}
\hline & & (1) & (2) & (3) & (4) & (5) & (6) & (7) \\
\hline (1) & $r_{A V^{\mathrm{a}}}$ & 1 & & & & & & \\
\hline (2) & DiscSaidin & $-0.103 * * *$ & 1 & & & & & \\
\hline (3) & DiscScaled & $-0.141 * * *$ & $0.305 * * *$ & 1 & & & & \\
\hline (4) & DiscRaw & $-0.139 * * *$ & $0.472 * * *$ & $0.948 * * *$ & 1 & & & \\
\hline (5) & $G d w B V^{\mathrm{a}}$ & -0.033 & -0.005 & $0.148 * * *$ & $0.168 * * *$ & 1 & & \\
\hline (6) & Readability & $-0.143 * * *$ & $0.115^{* * *}$ & $0.078^{* *}$ & 0.057 & 0.010 & 1 & \\
\hline (7) & $A W C A^{\mathrm{a}}$ & $0.071^{* *}$ & $0.082 * *$ & -0.021 & -0.017 & $-0.123 * * *$ & 0.040 & 1 \\
\hline (8) & $R O A^{\mathrm{a}}$ & $-0.339 * * *$ & 0.007 & -0.008 & -0.031 & $-0.087 * *$ & $0.256^{* * *}$ & $-0.098 * * *$ \\
\hline (9) & $M 2 B^{a}$ & $-0.282 * * *$ & $0.082 * *$ & 0.018 & 0.005 & $0.215^{* * *}$ & $0.251 * * *$ & 0.042 \\
\hline (10) & Leverage ${ }^{\mathrm{a}}$ & $0.086^{* *}$ & 0.039 & 0.004 & 0.011 & $0.362 * * *$ & $-0.145^{* * *}$ & $0.093 * * *$ \\
\hline (11) & Size & $-0.209^{* * *}$ & $-0.088^{* *}$ & $-0.071^{* *}$ & -0.039 & $-0.121^{* * *}$ & $-0.256^{* * *}$ & $-0.161 * * *$ \\
\hline (12) & rVar & $0.119 * * *$ & 0.005 & -0.020 & -0.034 & -0.043 & -0.027 & $0.188^{* * *}$ \\
\hline (13) & Dispersion ${ }^{\mathrm{a}}$ & -0.047 & $0.111 * * *$ & $0.205 * * *$ & $0.190 * * *$ & -0.009 & $0.243 * * *$ & 0.055 \\
\hline (14) & MrktDev & $-0.203 * * *$ & $0.166^{* * *}$ & $0.233 * * *$ & $0.235 * * *$ & 0.006 & $0.256 * * *$ & 0.001 \\
\hline (15) & Enforcement & $-0.192 * * *$ & $0.174 * * *$ & $0.216^{* * *}$ & $0.206 * * *$ & $0.075^{* *}$ & $0.081 * *$ & 0.024 \\
\hline
\end{tabular}

(continued on next page) 


\begin{tabular}{|c|c|c|c|c|c|c|c|c|c|}
\hline & & (8) & (9) & (10) & (11) & (12) & (13) & (14) & (15) \\
\hline (8) & $R O A^{\mathrm{a}}$ & 1 & & & & & & & \\
\hline (9) & $M 2 B^{a}$ & $0.526 * * *$ & 1 & & & & & & \\
\hline (10) & Leverage $^{\text {a }}$ & $-0.161 * * *$ & $0.301 * * *$ & 1 & & & & & \\
\hline (11) & Size & $0.181 * * *$ & $0.074 * *$ & $-0.067 *$ & 1 & & & & \\
\hline (12) & $r V a r$ & $-0.269 * * *$ & $-0.197 * * *$ & 0.023 & $-0.300 * * *$ & 1 & & & \\
\hline (13) & Dispersion $^{\text {a }}$ & $0.078 * *$ & $0.114 * * *$ & 0.048 & $-0.072 * *$ & 0.020 & 1 & & \\
\hline (14) & MrktDev & $0.234 * * *$ & $0.278 * * *$ & $-0.070 * *$ & 0.015 & $-0.134 * * *$ & $0.249 * * *$ & 1 & \\
\hline (15) & Enforcement & $0.083 * *$ & $0.136^{* * *}$ & $-0.088^{* *}$ & 0.037 & 0.027 & $0.246^{* * *}$ & $0.235^{* * *}$ & 1 \\
\hline
\end{tabular}

This table reports Pearson's correlation coefficients regarding all variables used in the main analyses. $r_{A V}$ refers to implied cost of equity capital (ICC), calculated as simple average of $r_{C T}$ (Claus and Thomas 2001), $r_{G L S}$ (Gebhardt et al. 2001), $r_{G M}$ (Gode and Mohanran 2003), $r_{M P E G}$ (Easton 2004). Further information about the ICC models can be found in Appendices B and C. DiscSaidin is a disclosure score which weights each disclosure item by the percentage of firms in the sample that do not comply with the item (Hodgdon et al., 2008). DiscScaled and DiscRaw are transformations of actual mandatory disclosure levels (Francis et al., 2005). DiscRaw is the difference between a firm's disclosure and the country-minimum score the firm is incorporated in. DiscScaled is DiscRaw scaled by the country-minimum score. GdwBV is goodwill (GDW from Compustat) to book value of equity (WC03501). Readability is the natural logarithm of page number in the annual report (PageCount; see Table 4) multiplied by -1 (Lawrence 2013). $A W C A$ is the absolute value of abnormal working capital accruals scaled by the end-of-the-year total assets $($ DeFond and Park 2001$)$. $A W C A=\left(W C_{t}-W C_{t-1} * S_{t} / S_{t-1}\right) /$ $T A_{\mathrm{t}}$. WC stands for working capital accruals, computed as current assets (WC02201) - cash \& equivalents (WC02001) - current liabilities (WC03101) + short term debt (WC03051). $S$ and TA stand for sales and total assets (WC02999), respectively. ROA is return on assets calculated as the ratio between net income and total assets (WC01751 / WC02999). M2B is the market value to book value of equity. Leverage is the ratio between total debt and book value of equity (WC03255/WC03501). Size is the natural logarithm of market value (Worldscope item WC08001; see Table 4). $r$ Var is the return variance over the financial year. All accounting and market data refer to year $t=0$. Dispersion is the standard deviation of the last forecast before earnings announcement. MrktDev is the market capitalisation of listed companies as a \% of GDP. Enforcement is an index capturing the strength of the enforcement body in each country (Brown et al., 2014).

${ }^{a}$ Variables winsorised at the 2 nd and 98 th percentiles. $*$, **, *** denote significance at the $10 \%, 5 \%$ and $1 \%$ level respectively. 
Table 6 - Descriptive statistics when splitting the sample into firms that meet $($ MrktMet $=1)$ or not $($ MrktMet $=0)$ market expectations with regard to recognition of goodwill impairment loss.

\begin{tabular}{|c|c|c|c|c|c|c|c|c|c|c|}
\hline \multirow[b]{2}{*}{ Variable } & \multicolumn{4}{|c|}{ MrktMet=0 } & \multicolumn{4}{|c|}{ MrktMet=1 } & \multicolumn{2}{|c|}{ Tests for difference } \\
\hline & $\mathbf{N}$ & Mean & StDev & Median & $\mathbf{N}$ & Mean & StDev & Median & T-test & $\begin{array}{c}\text { MannWhitney } \\
\text { test }\end{array}$ \\
\hline$r_{A V}$ & 248 & 0.115 & 0.043 & 0.112 & 583 & 0.108 & 0.039 & 0.104 & $2.248 * *$ & $2.955^{* * *}$ \\
\hline DiscSaidin & 248 & 0.553 & 0.218 & 0.551 & 583 & 0.569 & 0.267 & 0.555 & -0.791 & -0.327 \\
\hline DiscScaled & 248 & 0.471 & 0.390 & 0.391 & 583 & 0.675 & 0.603 & 0.500 & $-4.922 * * *$ & $-3.535 * * *$ \\
\hline DiscRaw & 248 & 0.233 & 0.141 & 0.231 & 583 & 0.293 & 0.190 & 0.278 & $-4.487 * * *$ & $-4.002 * * *$ \\
\hline$G d w B V$ & 248 & 0.735 & 1.159 & 0.555 & 583 & 0.684 & 0.754 & 0.501 & 0.753 & 1.106 \\
\hline MaterialIL & 248 & 0.270 & 0.445 & 0.000 & 583 & 0.009 & 0.092 & 0.000 & $13.537 * * *$ & $12.258 * * *$ \\
\hline MaterialBC & 248 & 0.770 & 0.422 & 1.000 & 583 & 0.703 & 0.457 & 1.000 & $1.975 * *$ & $1.971 * *$ \\
\hline Readability & 248 & -5.247 & 0.453 & -5.252 & 583 & -5.193 & 0.410 & -5.170 & $-1.668 * *$ & -1.393 \\
\hline$A W C A^{\mathrm{a}}$ & 248 & 0.029 & 0.038 & 0.016 & 583 & 0.025 & 0.029 & 0.017 & $1.867 * *$ & 0.163 \\
\hline$R O A^{\mathrm{a}}$ & 248 & 0.030 & 0.071 & 0.031 & 583 & 0.055 & 0.054 & 0.050 & $-5.715^{* * *}$ & $-6.394 * * *$ \\
\hline$M 2 B^{\mathrm{a}}$ & 248 & 2.241 & 3.470 & 1.545 & 583 & 2.857 & 3.305 & 2.110 & $-2.422 * * *$ & $-5.175 * * *$ \\
\hline Leverage $^{\text {a }}$ & 248 & 1.253 & 1.703 & 0.742 & 583 & 1.111 & 1.637 & 0.699 & 1.127 & $1.673^{*}$ \\
\hline Size & 248 & 9.075 & 1.173 & 9.037 & 583 & 8.969 & 1.119 & 8.865 & 1.234 & 1.437 \\
\hline$r V a r$ & 248 & 0.014 & 0.018 & 0.009 & 583 & 0.010 & 0.013 & 0.006 & $3.822 * * *$ & $5.020 * * *$ \\
\hline Dispersion $^{\text {a }}$ & 248 & 0.908 & 2.284 & 0.250 & 583 & 1.038 & 2.196 & 0.320 & -0.722 & $-1.833^{*}$ \\
\hline MrktDev & 248 & 0.681 & 0.374 & 0.566 & 583 & 0.807 & 0.485 & 0.703 & $-3.664 * * *$ & $-3.368 * * *$ \\
\hline Enforcement & 248 & 18 & 4 & 19 & 583 & 19 & 4 & 21 & $-2.179 * * *$ & $-2.927 * * *$ \\
\hline
\end{tabular}

The table reports descriptive statistics when splitting the sample into firms that meet (MrktMet $=1)$ or not $($ MrktMet $=0)$ market expectations with regard to recognition of goodwill impairment loss. We categorise firms following Ramanna and Watts (2012). $r_{A V}$ refers to implied cost of equity capital (ICC), calculated as simple average of $r_{C T}$ (Claus and Thomas 2001), $r_{G L S}$ (Gebhardt et al. 2001), $r_{G M}$ (Gode and Mohanran 2003), $r_{M P E G}$ (Easton 2004). DiscSaidin is a disclosure score that weights each disclosure item by the percentage of firms in the sample that do not comply with the item (Hodgdon et al., 2008). DiscScaled and DiscRaw are transformations of actual mandatory disclosure levels (Francis et al., 2005). DiscRaw is the difference between a firm's disclosure and the country-minimum score the firm is incorporated in. DiscScaled is DiscRaw scaled by the country-minimum score. GdwBV is goodwill (GDW from Compustat) to book value of equity (WC03501). MaterialIL stands for material impairment loss and MaterialBC for material business combination. Readability is the natural logarithm of page number in the annual report (PageCount; see Table 4) multiplied by -1 (Lawrence 2013). AWCA is the absolute value of abnormal working capital accruals scaled by the end-of-the-year total assets $(D e F o n d$ and Park 2001$) . A W C A=\left(W C_{t}-W C_{t}\right.$ $\left.{ }_{1} * S_{t} / S_{t-1}\right) / T A_{t}$. WC stands for working capital accruals, computed as current assets (WC02201) - cash \& equivalents (WC02001) - current liabilities (WC03101) + short term debt (WC03051). $S$ and TA stand for sales and total assets (WC02999), respectively. ROA is return on assets calculated as the ratio between net income and total assets (WC01751 / WC02999). M2B is the market value to book value of equity. Leverage is the ratio between total debt and book value of equity (WC03255/WC03501). Size is the natural logarithm of market value (Worldscope item WC08001; see Table 4). rVar is the return variance over the financial year. All accounting and market data refer to year $t=0$. Dispersion is the standard deviation of the last forecast before earnings announcement. MrktDev is the market capitalisation of listed companies as a \% of GDP. Enforcement is an index capturing the strength of the enforcement body (Brown et al., 2014).

${ }^{a}$ Variables winsorised at the 2 nd and 98 th percentiles.*, $* *, * * *$ denote significance at the $10 \%, 5 \%$ and $1 \%$ level respectively. 
Table 7 - Regression results for full sample and splitting the sample across firms meeting the market expectations

\begin{tabular}{|c|c|c|c|c|c|c|c|c|c|}
\hline VARIABLES & \multicolumn{3}{|c|}{ Full Sample } & \multicolumn{3}{|c|}{ MrktMet $=0$} & \multicolumn{3}{|c|}{ MrktMet $=1$} \\
\hline $\begin{array}{l}\text { Constant } \\
\text { DiscSaidin }\end{array}$ & $\begin{array}{c}0.166^{* * *} \\
(5.74) \\
-0.011^{* *} \\
(-2.07)\end{array}$ & $\begin{array}{c}0.156 * * * \\
(5.58)\end{array}$ & $\begin{array}{c}0.157 * * * \\
(5.59)\end{array}$ & $\begin{array}{c}0.172^{* * *} \\
(4.23) \\
-0.016^{* *} \\
(-2.31)\end{array}$ & $\begin{array}{c}0.171^{* * *} \\
(4.49)\end{array}$ & $\begin{array}{c}0.169 * * * \\
(4.39)\end{array}$ & $\begin{array}{c}0.177 * * * \\
(5.35) \\
-0.014 \\
(-1.30)\end{array}$ & $\begin{array}{c}0.164 * * * \\
(5.13)\end{array}$ & $\begin{array}{c}0.164 * * * \\
(5.14)\end{array}$ \\
\hline DiscScaled & & $\begin{array}{c}-0.007 * * \\
(-2.37)\end{array}$ & & & $\begin{array}{c}-0.022 * * * \\
(-3.02)\end{array}$ & & & $\begin{array}{l}-0.005 \\
(-1.25)\end{array}$ & \\
\hline DiscRaw & & & $\begin{array}{c}-0.020 * * \\
(-2.37)\end{array}$ & & & $\begin{array}{c}-0.054 * * * \\
(-2.65)\end{array}$ & & & $\begin{array}{l}-0.017 \\
(-1.37)\end{array}$ \\
\hline$G d w B V^{\mathrm{a}}$ & $\begin{array}{l}-0.001 \\
(-0.65)\end{array}$ & $\begin{array}{l}-0.001 \\
(-0.50)\end{array}$ & $\begin{array}{l}-0.001 \\
(-0.45)\end{array}$ & $\begin{array}{l}0.003 \\
(1.42)\end{array}$ & $\begin{array}{l}0.003^{*} \\
(1.83)\end{array}$ & $\begin{array}{c}0.003^{*} \\
(1.91)\end{array}$ & $\begin{array}{c}-0.004^{*} \\
(-1.66)\end{array}$ & $\begin{array}{l}-0.003 \\
(-1.46)\end{array}$ & $\begin{array}{l}-0.003 \\
(-1.42)\end{array}$ \\
\hline Readability & $\begin{array}{c}-0.007 * \\
(-1.83)\end{array}$ & $\begin{array}{c}-0.007 * \\
(-1.74)\end{array}$ & $\begin{array}{c}-0.007^{*} \\
(-1.74)\end{array}$ & $\begin{array}{l}-0.008 \\
(-1.31)\end{array}$ & $\begin{array}{l}-0.008 \\
(-1.43)\end{array}$ & $\begin{array}{l}-0.008 \\
(-1.40)\end{array}$ & $\begin{array}{l}-0.005 \\
(-0.97)\end{array}$ & $\begin{array}{l}-0.006 \\
(-1.17)\end{array}$ & $\begin{array}{l}-0.006 \\
(-1.18)\end{array}$ \\
\hline$A W C A^{\mathrm{a}}$ & $\begin{array}{l}0.053 \\
(1.09)\end{array}$ & $\begin{array}{l}0.048 \\
(0.96)\end{array}$ & $\begin{array}{l}0.049 \\
(0.98)\end{array}$ & $\begin{array}{c}0.209 * * \\
(2.35)\end{array}$ & $\begin{array}{c}0.197 * * \\
(2.25)\end{array}$ & $\begin{array}{c}0.199 * * \\
(2.27)\end{array}$ & $\begin{array}{l}-0.025 \\
(-0.41)\end{array}$ & $\begin{array}{l}-0.032 \\
(-0.50)\end{array}$ & $\begin{array}{l}-0.031 \\
(-0.48)\end{array}$ \\
\hline$R O A^{\mathrm{a}}$ & $\begin{array}{c}-0.139 * * * \\
(-3.08)\end{array}$ & $\begin{array}{c}-0.141 * * * \\
(-3.14)\end{array}$ & $\begin{array}{c}-0.142 * * * \\
(-3.14)\end{array}$ & $\begin{array}{c}-0.208 * * * \\
(-2.97)\end{array}$ & $\begin{array}{c}-0.235 * * * \\
(-3.43)\end{array}$ & $\begin{array}{c}-0.237 * * * \\
(-3.40)\end{array}$ & $\begin{array}{c}-0.110 * * \\
(-1.98)\end{array}$ & $\begin{array}{c}-0.114 * * \\
(-2.02)\end{array}$ & $\begin{array}{c}-0.114^{* *} \\
(-2.02)\end{array}$ \\
\hline$M 2 B^{\mathrm{a}}$ & $\begin{array}{l}-0.002 \\
(-1.35)\end{array}$ & $\begin{array}{l}-0.002 \\
(-1.43)\end{array}$ & $\begin{array}{l}-0.002 \\
(-1.46)\end{array}$ & $\begin{array}{l}-0.005 \\
(-1.62)\end{array}$ & $\begin{array}{c}-0.005^{*} \\
(-1.68)\end{array}$ & $\begin{array}{c}-0.005^{*} \\
(-1.69)\end{array}$ & $\begin{array}{l}-0.002 \\
(-1.10)\end{array}$ & $\begin{array}{l}-0.002 \\
(-1.11)\end{array}$ & $\begin{array}{l}-0.002 \\
(-1.14)\end{array}$ \\
\hline Leverage $^{\text {a }}$ & $\begin{array}{l}0.002 \\
(0.72)\end{array}$ & $\begin{array}{l}0.001 \\
(0.61)\end{array}$ & $\begin{array}{l}0.002 \\
(0.63)\end{array}$ & $\begin{array}{l}-0.001 \\
(-0.15)\end{array}$ & $\begin{array}{l}-0.002 \\
(-0.49)\end{array}$ & $\begin{array}{l}-0.001 \\
(-0.42)\end{array}$ & $\begin{array}{l}0.003 \\
(0.89)\end{array}$ & $\begin{array}{l}0.002 \\
(0.71)\end{array}$ & $\begin{array}{l}0.002 \\
(0.73)\end{array}$ \\
\hline Size & $\begin{array}{c}-0.007 * * * \\
(-3.18)\end{array}$ & $\begin{array}{c}-0.007 * * * \\
(-3.14)\end{array}$ & $\begin{array}{c}-0.006^{* * * *} \\
(-3.10)\end{array}$ & $\begin{array}{c}-0.008 * * \\
(-2.32)\end{array}$ & $\begin{array}{c}-0.008 * * \\
(-2.43)\end{array}$ & $\begin{array}{c}-0.007 * * \\
(-2.35)\end{array}$ & $\begin{array}{c}-0.006^{* * * *} \\
(-2.89)\end{array}$ & $\begin{array}{c}-0.006 * * * \\
(-2.76)\end{array}$ & $\begin{array}{c}-0.006 * * * \\
(-2.74)\end{array}$ \\
\hline rVar & $\begin{array}{l}-0.013 \\
(-0.13)\end{array}$ & $\begin{array}{l}-0.020 \\
(-0.22)\end{array}$ & $\begin{array}{l}-0.023 \\
(-0.25)\end{array}$ & $\begin{array}{l}-0.082 \\
(-0.65)\end{array}$ & $\begin{array}{l}-0.069 \\
(-0.60)\end{array}$ & $\begin{array}{l}-0.079 \\
(-0.66)\end{array}$ & $\begin{array}{l}0.019 \\
(0.14)\end{array}$ & $\begin{array}{l}0.018 \\
(0.13)\end{array}$ & $\begin{array}{l}0.015 \\
(0.11)\end{array}$ \\
\hline Dispersion $^{\text {a }}$ & $\begin{array}{l}0.001 \\
(1.09)\end{array}$ & $\begin{array}{l}0.001 \\
(1.22)\end{array}$ & $\begin{array}{l}0.001 \\
(1.21)\end{array}$ & $\begin{array}{l}-0.001 \\
(-0.08)\end{array}$ & $\begin{array}{l}0.001 \\
(0.33)\end{array}$ & $\begin{array}{l}0.001 \\
(0.26)\end{array}$ & $\begin{array}{l}0.001 \\
(1.03)\end{array}$ & $\begin{array}{l}0.001 \\
(1.13)\end{array}$ & $\begin{array}{l}0.001 \\
(1.12)\end{array}$ \\
\hline MrktDev & $\begin{array}{c}-0.014 * * \\
(-2.52)\end{array}$ & $\begin{array}{c}-0.011 * * \\
(-2.13)\end{array}$ & $\begin{array}{c}-0.011 * * \\
(-2.13)\end{array}$ & $\begin{array}{c}-0.023 * * \\
(-2.30)\end{array}$ & $\begin{array}{l}-0.013 \\
(-1.41)\end{array}$ & $\begin{array}{l}-0.015 \\
(-1.60)\end{array}$ & $\begin{array}{c}-0.012 * * \\
(-2.13)\end{array}$ & $\begin{array}{c}-0.012 * * \\
(-2.03)\end{array}$ & $\begin{array}{c}-0.012 * * \\
(-1.97)\end{array}$ \\
\hline Enforcement & $\begin{array}{c}-0.001 * \\
(-1.77)\end{array}$ & $\begin{array}{c}-0.001^{*} \\
(-1.77)\end{array}$ & $\begin{array}{c}-0.001 * \\
(-1.77)\end{array}$ & $\begin{array}{l}-0.001 \\
(-0.84)\end{array}$ & $\begin{array}{l}-0.001 \\
(-0.90)\end{array}$ & $\begin{array}{l}-0.001 \\
(-0.90)\end{array}$ & $\begin{array}{c}-0.001 * * \\
(-2.00)\end{array}$ & $\begin{array}{c}-0.001 * * \\
(-2.02)\end{array}$ & $\begin{array}{c}-0.001 * * \\
(-2.02)\end{array}$ \\
\hline $\begin{array}{l}\text { Industry dummies } \\
\text { Year dummies }\end{array}$ & $\begin{array}{l}\text { Included } \\
\text { Included }\end{array}$ & $\begin{array}{l}\text { Included } \\
\text { Included }\end{array}$ & $\begin{array}{l}\text { Included } \\
\text { Included }\end{array}$ & $\begin{array}{l}\text { Included } \\
\text { Included }\end{array}$ & $\begin{array}{l}\text { Included } \\
\text { Included }\end{array}$ & $\begin{array}{l}\text { Included } \\
\text { Included }\end{array}$ & $\begin{array}{l}\text { Included } \\
\text { Included }\end{array}$ & $\begin{array}{l}\text { Included } \\
\text { Included }\end{array}$ & $\begin{array}{l}\text { Included } \\
\text { Included }\end{array}$ \\
\hline $\begin{array}{l}N \\
F\end{array}$ & $\begin{array}{c}831 \\
4.27 * * *\end{array}$ & $\begin{array}{c}831 \\
4.38 * * *\end{array}$ & $\begin{array}{c}831 \\
4.39 * * *\end{array}$ & $\begin{array}{c}248 \\
4.27 * * *\end{array}$ & $\begin{array}{c}248 \\
4.50^{* * *}\end{array}$ & $\begin{array}{c}248 \\
4.51 * * *\end{array}$ & $\begin{array}{c}583 \\
4.82 * * *\end{array}$ & $\begin{array}{c}583 \\
4.69 * * *\end{array}$ & $\begin{array}{c}583 \\
4.69 * * *\end{array}$ \\
\hline $\begin{array}{l}R^{2} \text {-adj } \\
\text { Mean VIF }\end{array}$ & $\begin{array}{c}0.214 \\
1.73\end{array}$ & $\begin{array}{c}0.216 \\
1.77\end{array}$ & $\begin{array}{c}0.217 \\
1.76\end{array}$ & $\begin{array}{c}0.266 \\
1.71\end{array}$ & $\begin{array}{c}0.296 \\
1.74\end{array}$ & $\begin{array}{c}0.290 \\
1.72\end{array}$ & $\begin{array}{c}0.190 \\
1.81\end{array}$ & $\begin{array}{c}0.183 \\
1.86\end{array}$ & $\begin{array}{c}0.183 \\
1.85\end{array}$ \\
\hline
\end{tabular}

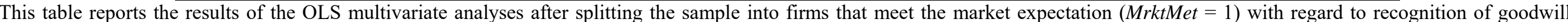

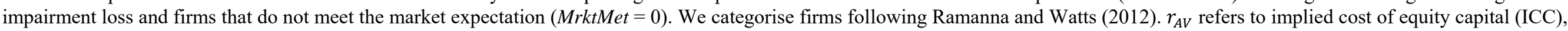




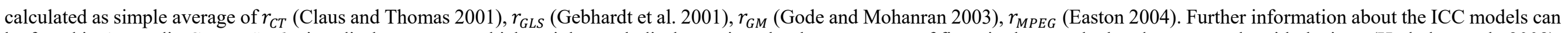

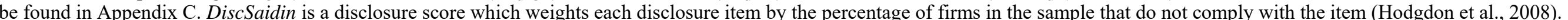

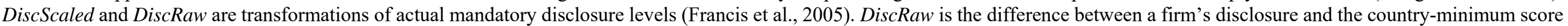

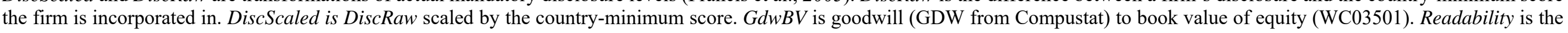

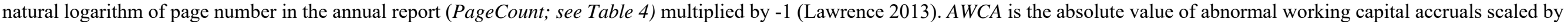

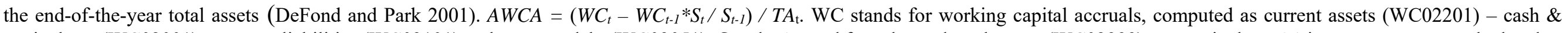

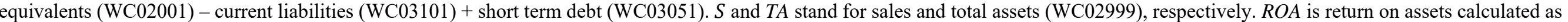

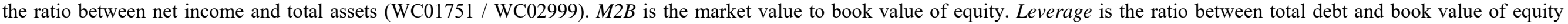

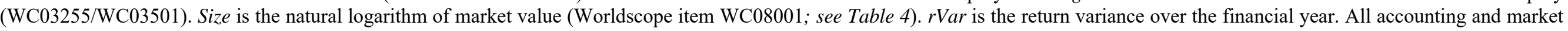

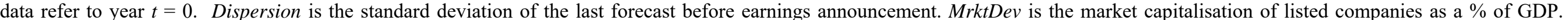

Enforcement is an index capturing the strength of the enforcement body in each country (Brown et al., 2014).

${ }^{a}$ Variables winsorised at the 2 nd and 98 th percentiles. *,**, *** denote significance at the $10 \%, 5 \%$ and $1 \%$ level respectively. 
Table 8 - Regression results splitting the sample across firms operating in countries with high and low enforcement

\begin{tabular}{|c|c|c|c|c|c|c|}
\hline VARIABLES & \multicolumn{3}{|c|}{$E n f H L=0$} & \multicolumn{3}{|c|}{$E n f H L=1$} \\
\hline Constant & $\begin{array}{c}0.175 * * * \\
(5.37)\end{array}$ & $\begin{array}{c}0.171^{* * *} \\
(5.32)\end{array}$ & $\begin{array}{c}0.172^{* * * *} \\
(5.40)\end{array}$ & $\begin{array}{c}0.242 * * * \\
(4.50)\end{array}$ & $\begin{array}{c}0.240^{* * *} \\
(4.54)\end{array}$ & $\begin{array}{c}0.243 * * * \\
(4.65)\end{array}$ \\
\hline DiscSaidin & $\begin{array}{l}-0.002 \\
(-0.27)\end{array}$ & & & $\begin{array}{c}-0.013^{*} \\
(-1.95)\end{array}$ & & \\
\hline DiscScaled & & $\begin{array}{l}-0.003 \\
(-0.54)\end{array}$ & & & $\begin{array}{c}-0.010 * * * \\
(-2.74)\end{array}$ & \\
\hline DiscRaw & & & $\begin{array}{l}-0.007 \\
(-0.54)\end{array}$ & & & $\begin{array}{c}-0.029 * * * \\
(-2.73)\end{array}$ \\
\hline$G d w B V^{\mathrm{a}}$ & $\begin{array}{l}0.005 \\
(0.80)\end{array}$ & $\begin{array}{l}0.005 \\
(0.86)\end{array}$ & $\begin{array}{l}0.006 \\
(0.88)\end{array}$ & $\begin{array}{l}-0.001 \\
(-0.41)\end{array}$ & $\begin{array}{l}-0.001 \\
(-0.19)\end{array}$ & $\begin{array}{l}-0.001 \\
(-0.12)\end{array}$ \\
\hline Readability & $\begin{array}{l}0.002 \\
(0.45)\end{array}$ & $\begin{array}{l}0.002 \\
(0.39)\end{array}$ & $\begin{array}{l}0.002 \\
(0.38)\end{array}$ & $\begin{array}{l}-0.009 \\
(-1.50)\end{array}$ & $\begin{array}{l}-0.008 \\
(-1.34)\end{array}$ & $\begin{array}{l}-0.008 \\
(-1.35)\end{array}$ \\
\hline$A W C A^{\mathrm{a}}$ & $\begin{array}{c}0.172 * * \\
(2.63)\end{array}$ & $\begin{array}{c}0.175^{* * * *} \\
(2.68)\end{array}$ & $\begin{array}{c}0.174 * * * \\
(2.67)\end{array}$ & $\begin{array}{l}0.034 \\
(0.62)\end{array}$ & $\begin{array}{l}0.030 \\
(0.52)\end{array}$ & $\begin{array}{l}0.031 \\
(0.54)\end{array}$ \\
\hline$R O A^{\mathrm{a}}$ & $\begin{array}{c}-0.159 * * \\
(-2.33)\end{array}$ & $\begin{array}{c}-0.159 * * \\
(-2.37)\end{array}$ & $\begin{array}{c}-0.160 * * \\
(-2.37)\end{array}$ & $\begin{array}{c}-0.129 * * \\
(-2.32)\end{array}$ & $\begin{array}{c}-0.130 * * \\
(-2.40)\end{array}$ & $\begin{array}{c}-0.132 * * \\
(-2.41)\end{array}$ \\
\hline$M 2 B^{a}$ & $\begin{array}{c}-0.011 * * * \\
(-4.72)\end{array}$ & $\begin{array}{c}-0.011 * * * \\
(-4.77)\end{array}$ & $\begin{array}{c}-0.011 * * * \\
(-4.79)\end{array}$ & $\begin{array}{c}0.001 \\
(0.25)\end{array}$ & $\begin{array}{l}0.001 \\
(0.15)\end{array}$ & $\begin{array}{l}0.001 \\
(0.12)\end{array}$ \\
\hline Leverage $^{\text {a }}$ & $\begin{array}{l}0.004 \\
(1.11)\end{array}$ & $\begin{array}{l}0.003 \\
(1.03)\end{array}$ & $\begin{array}{l}0.003 \\
(1.03)\end{array}$ & $\begin{array}{l}-0.001 \\
(-0.37)\end{array}$ & $\begin{array}{l}-0.001 \\
(-0.36)\end{array}$ & $\begin{array}{l}-0.001 \\
(-0.32)\end{array}$ \\
\hline Size & $\begin{array}{l}-0.002 \\
(-0.61)\end{array}$ & $\begin{array}{l}-0.002 \\
(-0.61)\end{array}$ & $\begin{array}{l}-0.002 \\
(-0.61)\end{array}$ & $\begin{array}{c}-0.007 * * * \\
(-2.95)\end{array}$ & $\begin{array}{c}-0.007 * * * \\
(-2.95)\end{array}$ & $\begin{array}{c}-0.007 * * * \\
(-2.87)\end{array}$ \\
\hline rVar & $\begin{array}{l}0.402^{*} \\
(1.70)\end{array}$ & $\begin{array}{l}0.401^{*} \\
(1.71)\end{array}$ & $\begin{array}{l}0.404 * \\
(1.71)\end{array}$ & $\begin{array}{l}-0.064 \\
(-0.72)\end{array}$ & $\begin{array}{l}-0.072 \\
(-0.85)\end{array}$ & $\begin{array}{l}-0.077 \\
(-0.89)\end{array}$ \\
\hline Dispersion $^{\text {a }}$ & $\begin{array}{l}0.001 \\
(0.17)\end{array}$ & $\begin{array}{l}0.001 \\
(0.20)\end{array}$ & $\begin{array}{l}0.001 \\
(0.21)\end{array}$ & $\begin{array}{l}0.002 \\
(1.31)\end{array}$ & $\begin{array}{l}0.002 \\
(1.53)\end{array}$ & $\begin{array}{l}0.002 \\
(1.50)\end{array}$ \\
\hline MrktDev & $\begin{array}{l}-0.009 \\
(-1.11)\end{array}$ & $\begin{array}{l}-0.008 \\
(-1.03)\end{array}$ & $\begin{array}{l}-0.008 \\
(-0.94)\end{array}$ & $\begin{array}{c}-0.016^{* *} \\
(-2.56)\end{array}$ & $\begin{array}{c}-0.012 * * \\
(-2.04)\end{array}$ & $\begin{array}{c}-0.012 * * \\
(-2.12)\end{array}$ \\
\hline Enforcement & $\begin{array}{l}-0.001 \\
(-0.35)\end{array}$ & $\begin{array}{l}-0.001 \\
(-0.22)\end{array}$ & $\begin{array}{l}-0.001 \\
(-0.25)\end{array}$ & $\begin{array}{c}-0.005^{* *} \\
(-2.53)\end{array}$ & $\begin{array}{c}-0.005^{* *} \\
(-2.43)\end{array}$ & $\begin{array}{c}-0.005^{* *} \\
(-2.53)\end{array}$ \\
\hline Industry dummies & Included & Included & Included & Included & Included & Included \\
\hline Year dummies & Included & Included & Included & Included & Included & Included \\
\hline$N$ & 306 & 306 & 306 & 525 & 525 & 525 \\
\hline$F$ & $7.40^{* * *}$ & $7.59 * * *$ & $7.42 * * *$ & $4.70 * * *$ & $4.89 * * *$ & $4.84 * * *$ \\
\hline$R^{2}$-adj & 0.376 & 0.376 & 0.377 & 0.216 & 0.223 & 0.224 \\
\hline Mean VIF & 2.23 & 2.27 & 2.25 & 1.77 & 1.84 & 1.81 \\
\hline
\end{tabular}

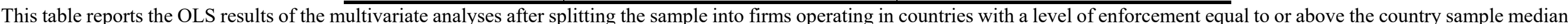

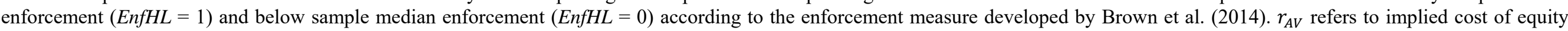




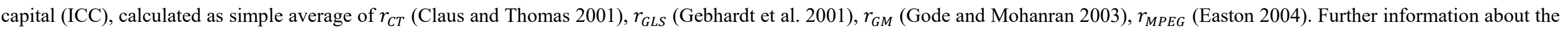

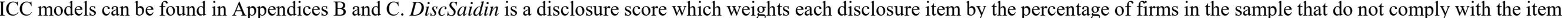

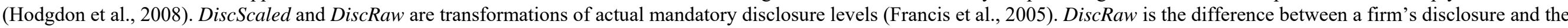

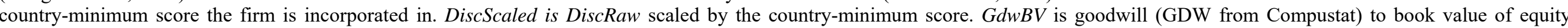

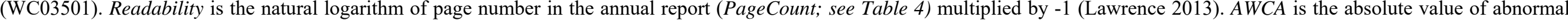

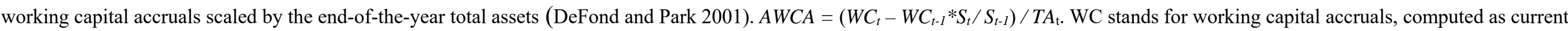

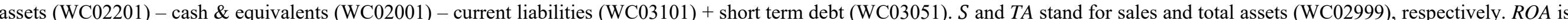

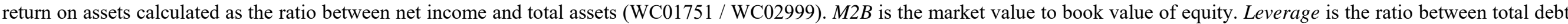

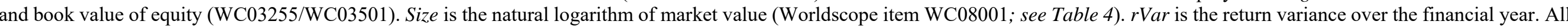

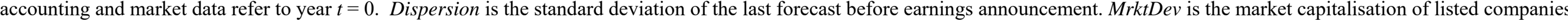
as a \% of GDP. Enforcement is an index capturing the strength of the enforcement body in each country (Brown et al., 2014).

${ }^{a}$ Variables winsorised at the 2 nd and 98 th percentiles. *, **,*** denote significance at the $10 \%, 5 \%$ and $1 \%$ level respectively. 
Table 9 - Regression results splitting the sample across firms operating in countries with high and low enforcement and firms meeting the market expectations

\begin{tabular}{|c|c|c|c|c|c|c|c|c|c|c|c|c|}
\hline \multirow{2}{*}{ VARIABLES } & \multicolumn{6}{|c|}{$\operatorname{EnfHL}=0$} & \multicolumn{6}{|c|}{$E n f H L=1$} \\
\hline & \multicolumn{3}{|c|}{ MrktMet $=0$} & \multicolumn{3}{|c|}{ MrktMet=1 } & \multicolumn{3}{|c|}{ MrktMet $=0$} & \multicolumn{3}{|c|}{ MrktMet=1 } \\
\hline DiscSaidin & $\begin{array}{c}0.136^{* * *} \\
(3.67) \\
0.012 \\
(0.77)\end{array}$ & $\begin{array}{c}0.145^{* * *} \\
(3.79)\end{array}$ & $\begin{array}{c}0.145^{* * *} \\
(3.82)\end{array}$ & $\begin{array}{c}0.198 * * * \\
(4.97) \\
-0.013 \\
(-1.26)\end{array}$ & $\begin{array}{c}0.173 * * * \\
(4.58)\end{array}$ & $\begin{array}{c}0.173 * * * \\
(4.60)\end{array}$ & $\begin{array}{c}0.309 * * * \\
(2.88) \\
-0.018^{* *} \\
(-2.08)\end{array}$ & $\begin{array}{c}0.314 * * * \\
(2.99)\end{array}$ & $\begin{array}{c}0.318^{* * *} \\
(3.10)\end{array}$ & $\begin{array}{c}0.256^{* * *} \\
(4.44) \\
-0.011 \\
(-1.51)\end{array}$ & $\begin{array}{c}0.254 * * * \\
(4.42)\end{array}$ & $\begin{array}{c}0.255^{* * *} \\
(4.47)\end{array}$ \\
\hline DiscScaled & & $\begin{array}{l}-0.004 \\
(-0.27)\end{array}$ & & & $\begin{array}{l}-0.002 \\
(-0.46)\end{array}$ & & & $\begin{array}{c}-0.027 * * * \\
(-3.02)\end{array}$ & & & $\begin{array}{l}-0.005 \\
(-1.39)\end{array}$ & \\
\hline DiscRaw & & & $\begin{array}{l}-0.006 \\
(-0.23)\end{array}$ & & & $\begin{array}{l}-0.010 \\
(-0.65)\end{array}$ & & & $\begin{array}{c}-0.077 * * * \\
(-2.72)\end{array}$ & & & $\begin{array}{l}-0.015 \\
(-1.37)\end{array}$ \\
\hline$G d w B V^{\mathrm{a}}$ & $\begin{array}{l}0.013 \\
(1.50)\end{array}$ & $\begin{array}{l}0.015 \\
(1.55)\end{array}$ & $\begin{array}{l}0.015 \\
(1.55)\end{array}$ & $\begin{array}{l}0.002 \\
(0.32)\end{array}$ & $\begin{array}{l}0.003 \\
(0.41)\end{array}$ & $\begin{array}{l}0.003 \\
(0.44)\end{array}$ & $\begin{array}{c}0.002 \\
(0.98)\end{array}$ & $\begin{array}{l}0.002 \\
(1.35)\end{array}$ & $\begin{array}{l}0.003 \\
(1.49)\end{array}$ & $\begin{array}{l}-0.002 \\
(-1.13)\end{array}$ & $\begin{array}{l}-0.002 \\
(-0.88)\end{array}$ & $\begin{array}{l}-0.002 \\
(-0.86)\end{array}$ \\
\hline Readability & $\begin{array}{l}-0.002 \\
(-0.23)\end{array}$ & $\begin{array}{l}0.001 \\
(0.07)\end{array}$ & $\begin{array}{l}0.001 \\
(0.06)\end{array}$ & $\begin{array}{c}0.035^{* * *} * \\
(4.02)\end{array}$ & $\begin{array}{c}0.032 * * * \\
(3.68)\end{array}$ & $\begin{array}{c}0.032 * * * \\
(3.73)\end{array}$ & $\begin{array}{c}-0.021 * * * \\
(-2.64)\end{array}$ & $\begin{array}{c}-0.016^{* *} \\
(-2.37)\end{array}$ & $\begin{array}{c}-0.015^{* *} \\
(-2.01)\end{array}$ & $\begin{array}{l}0.005 \\
(0.23)\end{array}$ & $\begin{array}{l}0.004 \\
(0.21)\end{array}$ & $\begin{array}{l}0.004 \\
(0.19)\end{array}$ \\
\hline$A W C A^{\mathrm{a}}$ & $\begin{array}{l}0.001 \\
(0.05)\end{array}$ & $\begin{array}{l}0.001 \\
(0.04)\end{array}$ & $\begin{array}{l}0.001 \\
(0.05)\end{array}$ & $\begin{array}{l}0.007 \\
(1.07)\end{array}$ & $\begin{array}{l}0.005 \\
(0.71)\end{array}$ & $\begin{array}{l}0.005 \\
(0.70)\end{array}$ & $\begin{array}{l}-0.008 \\
(-0.66)\end{array}$ & $\begin{array}{l}-0.007 \\
(-0.53)\end{array}$ & $\begin{array}{l}-0.006 \\
(-0.51)\end{array}$ & $\begin{array}{l}-0.007 \\
(-1.04)\end{array}$ & $\begin{array}{l}-0.006 \\
(-0.89)\end{array}$ & $\begin{array}{l}-0.006 \\
(-0.91)\end{array}$ \\
\hline$R O A^{\mathrm{a}}$ & $\begin{array}{c}0.338^{*} \\
(1.96)\end{array}$ & $\begin{array}{c}0.336^{*} \\
(1.98)\end{array}$ & $\begin{array}{c}0.335^{*} \\
(1.98)\end{array}$ & $\begin{array}{l}0.110 \\
(1.39)\end{array}$ & $\begin{array}{l}0.119 \\
(1.54)\end{array}$ & $\begin{array}{l}0.121 \\
(1.57)\end{array}$ & $\begin{array}{l}0.148 \\
(1.29)\end{array}$ & $\begin{array}{l}0.152 \\
(1.34)\end{array}$ & $\begin{array}{l}0.146 \\
(1.29)\end{array}$ & $\begin{array}{l}-0.032 \\
(-0.50)\end{array}$ & $\begin{array}{l}-0.039 \\
(-0.59)\end{array}$ & $\begin{array}{l}-0.038 \\
(-0.58)\end{array}$ \\
\hline$M 2 B^{a}$ & $\begin{array}{c}-0.361 * * * \\
(-3.14)\end{array}$ & $\begin{array}{c}-0.352 * * * \\
(-2.99)\end{array}$ & $\begin{array}{c}-0.351 * * * \\
(-2.99)\end{array}$ & $\begin{array}{l}-0.081 \\
(-1.23)\end{array}$ & $\begin{array}{l}-0.067 \\
(-1.02)\end{array}$ & $\begin{array}{l}-0.069 \\
(-1.05)\end{array}$ & $\begin{array}{c}-0.187^{*} \\
(-1.84)\end{array}$ & $\begin{array}{c}-0.190 * \\
(-1.89)\end{array}$ & $\begin{array}{c}-0.204 * * \\
(-2.03)\end{array}$ & $\begin{array}{c}-0.131^{*} \\
(-1.95)\end{array}$ & $\begin{array}{c}-0.134 * * \\
(-2.01)\end{array}$ & $\begin{array}{c}-0.134 * * \\
(-2.00)\end{array}$ \\
\hline Leverage $^{\text {a }}$ & $\begin{array}{c}-0.013 * * * \\
(-3.07)\end{array}$ & $\begin{array}{c}-0.013 * * * \\
(-3.06)\end{array}$ & $\begin{array}{c}-0.013 * * * \\
(-3.06)\end{array}$ & $\begin{array}{c}-0.010^{* * * *} \\
(-3.98)\end{array}$ & $\begin{array}{c}-0.010 * * * \\
(-3.97)\end{array}$ & $\begin{array}{c}-0.010 * * * \\
(-3.99)\end{array}$ & $\begin{array}{l}0.001 \\
(0.24)\end{array}$ & $\begin{array}{l}0.001 \\
(0.15)\end{array}$ & $\begin{array}{l}0.001 \\
(0.18)\end{array}$ & $\begin{array}{l}0.001 \\
(0.28)\end{array}$ & $\begin{array}{l}0.001 \\
(0.23)\end{array}$ & $\begin{array}{l}0.001 \\
(0.22)\end{array}$ \\
\hline Size & $\begin{array}{l}-0.002 \\
(-0.43)\end{array}$ & $\begin{array}{l}-0.003 \\
(-0.48)\end{array}$ & $\begin{array}{l}-0.003 \\
(-0.47)\end{array}$ & $\begin{array}{l}0.005 \\
(1.14)\end{array}$ & $\begin{array}{l}0.004 \\
(0.96)\end{array}$ & $\begin{array}{l}0.004 \\
(0.96)\end{array}$ & $\begin{array}{l}-0.008 \\
(-1.59)\end{array}$ & $\begin{array}{c}-0.008^{*} \\
(-1.79)\end{array}$ & $\begin{array}{c}-0.008^{*} \\
(-1.68)\end{array}$ & $\begin{array}{l}0.001 \\
(0.02)\end{array}$ & $\begin{array}{l}-0.001 \\
(-0.02)\end{array}$ & $\begin{array}{l}0.001 \\
(0.01)\end{array}$ \\
\hline rVar & $\begin{array}{l}-0.001 \\
(-0.17)\end{array}$ & $\begin{array}{l}-0.001 \\
(-0.26)\end{array}$ & $\begin{array}{l}-0.001 \\
(-0.26)\end{array}$ & $\begin{array}{l}-0.001 \\
(-0.34)\end{array}$ & $\begin{array}{l}-0.001 \\
(-0.21)\end{array}$ & $\begin{array}{l}-0.001 \\
(-0.20)\end{array}$ & $\begin{array}{c}-0.010 * * \\
(-2.34)\end{array}$ & $\begin{array}{c}-0.010^{* *} \\
(-2.46)\end{array}$ & $\begin{array}{c}-0.009 * * \\
(-2.34)\end{array}$ & $\begin{array}{c}-0.007 * * * \\
(-2.81)\end{array}$ & $\begin{array}{c}-0.006 * * * \\
(-2.75)\end{array}$ & $\begin{array}{c}-0.006 * * * \\
(-2.70)\end{array}$ \\
\hline Dispersion $^{\text {a }}$ & $\begin{array}{l}0.960 * \\
(1.94)\end{array}$ & $\begin{array}{l}0.987^{*} \\
(1.91)\end{array}$ & $\begin{array}{c}0.986^{*} \\
(1.91)\end{array}$ & $\begin{array}{l}0.428 \\
(1.57)\end{array}$ & $\begin{array}{l}0.401 \\
(1.53)\end{array}$ & $\begin{array}{l}0.403 \\
(1.53)\end{array}$ & $\begin{array}{l}-0.066 \\
(-0.41)\end{array}$ & $\begin{array}{l}-0.064 \\
(-0.50)\end{array}$ & $\begin{array}{l}-0.058 \\
(-0.44)\end{array}$ & $\begin{array}{l}-0.067 \\
(-0.53)\end{array}$ & $\begin{array}{l}-0.063 \\
(-0.50)\end{array}$ & $\begin{array}{l}-0.069 \\
(-0.55)\end{array}$ \\
\hline MrktDev & $\begin{array}{l}-0.001 \\
(-0.05)\end{array}$ & $\begin{array}{l}0.001 \\
(0.06)\end{array}$ & $\begin{array}{l}0.001 \\
(0.06)\end{array}$ & $\begin{array}{l}0.001 \\
(0.11)\end{array}$ & $\begin{array}{l}0.001 \\
(0.23)\end{array}$ & $\begin{array}{l}0.001 \\
(0.24)\end{array}$ & $\begin{array}{l}0.001 \\
(0.45)\end{array}$ & $\begin{array}{l}0.002 \\
(0.92)\end{array}$ & $\begin{array}{l}0.002 \\
(0.89)\end{array}$ & $\begin{array}{l}0.002 \\
(1.33)\end{array}$ & $\begin{array}{l}0.002 \\
(1.46)\end{array}$ & $\begin{array}{l}0.002 \\
(1.43)\end{array}$ \\
\hline Enforcement & $\begin{array}{l}-0.007 \\
(-0.36)\end{array}$ & $\begin{array}{l}-0.004 \\
(-0.16)\end{array}$ & $\begin{array}{l}-0.004 \\
(-0.18)\end{array}$ & $\begin{array}{l}-0.016 \\
(-1.63)\end{array}$ & $\begin{array}{l}-0.017 \\
(-1.64)\end{array}$ & $\begin{array}{l}-0.016 \\
(-1.49)\end{array}$ & $\begin{array}{l}-0.023 \\
(-1.63)\end{array}$ & $\begin{array}{l}-0.013 \\
(-0.97)\end{array}$ & $\begin{array}{l}-0.015 \\
(-1.15)\end{array}$ & $\begin{array}{c}-0.014 * * \\
(-2.14)\end{array}$ & $\begin{array}{c}-0.012 * \\
(-1.92)\end{array}$ & $\begin{array}{c}-0.013 * * \\
(-1.98)\end{array}$ \\
\hline $\begin{array}{l}\text { Industry dummies } \\
\text { Year dummies }\end{array}$ & $\begin{array}{l}\text { Included } \\
\text { Included }\end{array}$ & $\begin{array}{l}\text { Included } \\
\text { Included }\end{array}$ & $\begin{array}{l}\text { Included } \\
\text { Included }\end{array}$ & $\begin{array}{l}\text { Included } \\
\text { Included }\end{array}$ & $\begin{array}{l}\text { Included } \\
\text { Included }\end{array}$ & $\begin{array}{l}\text { Included } \\
\text { Included }\end{array}$ & $\begin{array}{l}\text { Included } \\
\text { Included }\end{array}$ & $\begin{array}{l}\text { Included } \\
\text { Included }\end{array}$ & $\begin{array}{l}\text { Included } \\
\text { Included }\end{array}$ & $\begin{array}{l}\text { Included } \\
\text { Included }\end{array}$ & $\begin{array}{l}\text { Included } \\
\text { Included }\end{array}$ & $\begin{array}{l}\text { Included } \\
\text { Included }\end{array}$ \\
\hline $\begin{array}{l}N \\
F\end{array}$ & $\begin{array}{c}110 \\
5.496\end{array}$ & $\begin{array}{c}110 \\
5.811\end{array}$ & $\begin{array}{c}110 \\
5.777\end{array}$ & $\begin{array}{c}196 \\
4.630\end{array}$ & $\begin{array}{c}196 \\
4.481\end{array}$ & $\begin{array}{c}196 \\
4.351\end{array}$ & $\begin{array}{c}138 \\
9.496\end{array}$ & $\begin{array}{c}138 \\
9.654\end{array}$ & $\begin{array}{c}138 \\
6.413\end{array}$ & $\begin{array}{c}387 \\
6.136\end{array}$ & $\begin{array}{c}387 \\
6.096\end{array}$ & $\begin{array}{c}387 \\
6.064\end{array}$ \\
\hline
\end{tabular}




\begin{tabular}{|c|c|c|c|c|c|c|c|c|c|c|c|c|}
\hline $\begin{array}{l}R^{2} \text {-adj } \\
\text { Mean VIF }\end{array}$ & $\begin{array}{c}0.479 \\
3.32\end{array}$ & $\begin{array}{c}0.476 \\
3.36\end{array}$ & $\begin{array}{c}0.476 \\
3.34\end{array}$ & $\begin{array}{c}0.346 \\
2.19\end{array}$ & $\begin{array}{c}0.338 \\
2.21\end{array}$ & $\begin{array}{c}0.339 \\
2.19\end{array}$ & $\begin{array}{c}0.266 \\
1.79\end{array}$ & $\begin{array}{c}0.324 \\
1.83\end{array}$ & $\begin{array}{c}0.318 \\
1.81\end{array}$ & $\begin{array}{c}0.185 \\
1.87\end{array}$ & $\begin{array}{c}0.184 \\
1.93\end{array}$ & $\begin{array}{r}0.184 \\
1.91\end{array}$ \\
\hline
\end{tabular}

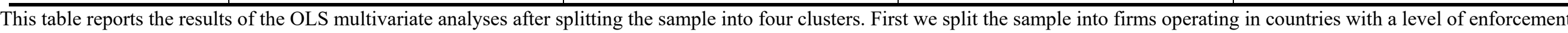

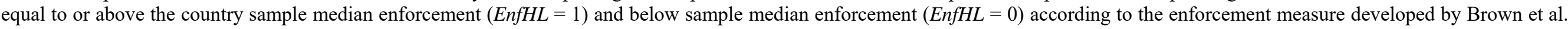

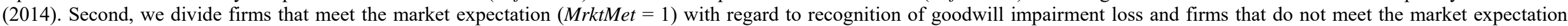

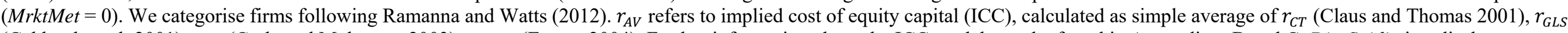

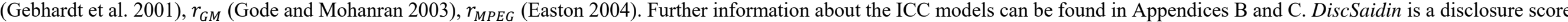

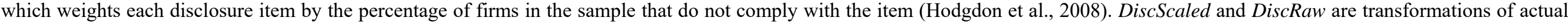

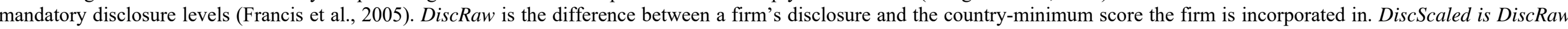

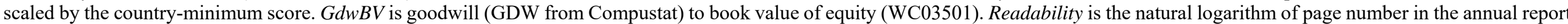

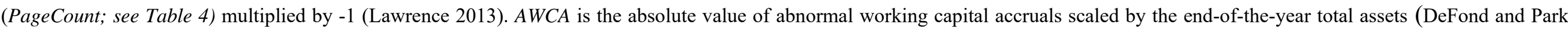

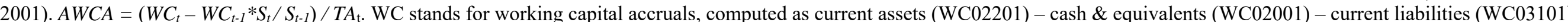

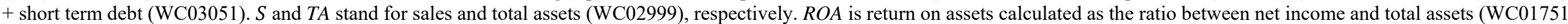

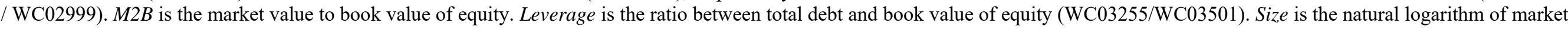

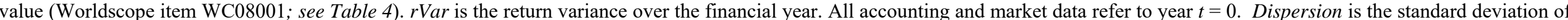

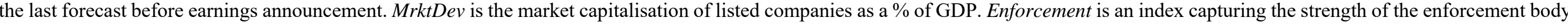
in each country (Brown et al., 2014).

${ }^{a}$ Variables winsorised at the 2 nd and 98 th percentiles. *,**, *** denote significance at the $10 \%, 5 \%$ and $1 \%$ level respectively. 